\title{
Health, obstetric outcomes and reproduction in women with vulvar pain or primary fear of childbirth
}

Louise Möller

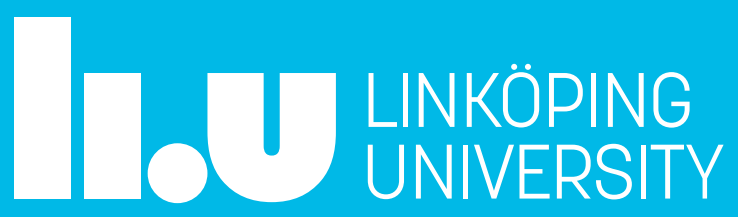




\section{Health, obstetric outcomes and}

\section{reproduction in women with vulvar pain or primary fear of childbirth}

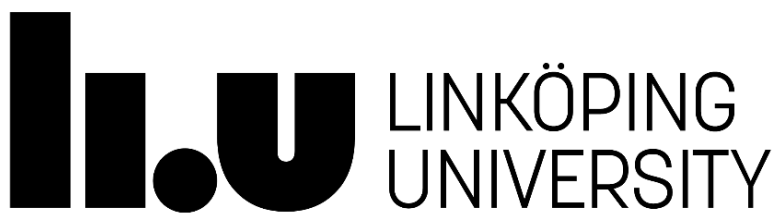

Division of Obstetrics and Gynaecology

Department of Clinical and Experimental Medicine

Faculty of Health Sciences

Linköping University, Sweden 
(C)Louise Möller, 2019

ISBN: 978-91-7685-077-0

ISSN: 0345-0082

Printed by LiU-tryck, Linköping 2019 


\section{Abstract}

Fear of childbirth (FOC) is common and affects approximately 5-20\% of all pregnant women. FOC is associated with giving birth by caesarean section on maternal request (CSMR). The rate of caesarean sections (CS) and CSMR has increased during the last decades. To decrease these women's fear, the rate of CSMR and to promote a more positive birth experience, many treatments for FOC have been evaluated. In Sweden, the treatment is individualized and given by obstetricians, midwives, psychologists or psychotherapists in the specialist care.

Women with FOC suffer more often from psychiatric illness and rate their general health as less good, which is important to consider when counselling these women and deciding on mode of delivery. Little is known about the long term obstetric and reproductive outcomes for women with FOC. Therefore, the aim of the studies on which this thesis is based was to compare psychiatric care before and after childbirth in women giving birth by CSMR to women giving birth by other modes of delivery and to follow the subsequent obstetric and reproductive outcomes in women receiving counselling for FOC in their first childbirth. Furthermore, we hypothesized that women with localized provoked vulvodynia (LPV) and/or vaginismus might fear vaginal childbirth and little is known about their reproduction and obstetric outcomes which is why we investigated the parity and obstetric outcomes in women diagnosed with LPV/vaginismus before first childbirth.

Based on data linked from several Swedish National registers, the prevalence of psychiatric in- and outpatient care before (paper I) and after first childbirth (paper II) was compared in primiparae giving birth by CSMR to primiparae giving birth by other modes of delivery. The prevalence of psychiatric disorders was found to be significantly higher in women giving birth by CSMR, indicating a severe burden of psychiatric illness in these women.

In paper III, also based on data from several Swedish National registers, a diagnosis of LPV/vaginismus before childbirth was shown to decrease the odds of giving birth. When giving birth these women had an increased risk of CS, especially CSMR. This could possibly indicate FOC in these women. Further, women with vaginismus had an increased risk of pelvic floor injuries.

Paper IV was a follow-up study of women who received counselling for FOC in their first pregnancy leading to parturition. It was based on data from medical records and a questionnaire. The women were followed 7-14 years after their first childbirth. Women treated for FOC more often gave birth by CS, rated their first birth experience as less positive 
and more often required counselling for FOC in their subsequent pregnancies compared to women without FOC in their first pregnancy. There were no significant differences in the rate of complications during pregnancy and childbirth compared to the other women. Women treated for FOC less often gave birth more than twice. Despite being given counselling and being exposed to childbirth almost one in five women felt fearful towards childbirth 7-14 years after the first childbirth.

In conclusion, women with FOC are a vulnerable group suffering from a significant burden of psychiatric illness. FOC is not easily treated; many women require counselling in subsequent pregnancies and many still fear childbirth after the childbearing years. Furthermore, LPV/vaginismus is a risk factor for giving birth by CSMR, possibly indicating FOC, and these women are less likely to give birth. Our study shows it is important not only to address sexual function in these women but reproductive function as well. Further studies are needed to establish how to optimize their care regarding fertility, antenatal, obstetric and post-partum care. 


\section{Contents}

Abstract

List of papers

List of abbreviations

Introduction 11

Fear of childbirth - Prevalence, definitions, causes and associated factors $\quad 11$

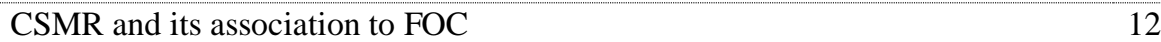

$\begin{array}{ll}\text { Treatment for FOC } & 13\end{array}$

$\begin{array}{ll}\text { Impact on reproduction } & 14\end{array}$

$\begin{array}{ll}\text { Psychiatric disorders } & 15\end{array}$

Vulvodynia 15

$\begin{array}{ll}\text { Aims } & 19\end{array}$

$\begin{array}{lll}\text { Methods } & 21\end{array}$

$\begin{array}{ll}\text { National registers } & 21\end{array}$

$\begin{array}{ll}\text { Medical records } & 22\end{array}$

$\begin{array}{ll}\text { Study populations and design } & 24\end{array}$

$\begin{array}{ll}\text { Paper I-II } & 24\end{array}$

Paper III 25

Paper IV 25

$\begin{array}{lr}\text { Main outcome measures } & 28\end{array}$

$\begin{array}{ll}\text { Paper I-II } & 28\end{array}$

$\begin{array}{ll}\text { Paper III } & 30\end{array}$

Paper IV 31

$\begin{array}{ll}\text { Statistics } & 32\end{array}$

$\begin{array}{ll}\text { Paper I } & 32\end{array}$

$\begin{array}{ll}\text { Paper II } & 32\end{array}$

Paper III 33

Paper IV 33

$\begin{array}{ll}\text { Ethical considerations } & 35\end{array}$ 


\begin{tabular}{lc}
\hline Summary of results & 37 \\
\hline Paper I & 37 \\
\hline Paper II & 37 \\
\hline Paper III & 39 \\
\hline Paper IV & 42 \\
\hline Discussion & 45 \\
\hline Main findings & 45 \\
\hline Methodological considerations & 46 \\
\hline Principal findings in light of other research & 52 \\
\hline Clinical implications & 54 \\
\hline Further research & 55 \\
\hline Conclusions & 57 \\
\hline Populärvetenskaplig sammanfattning & 59 \\
\hline Acknowledgements & 61 \\
\hline References & 63 \\
\hline
\end{tabular}




\section{List of papers}

This thesis is based on these papers that are referred to in the text by their roman numerals.

I. Sydsjö G, Möller L, Lilliecreutz C, Bladh M, Andolf E, Josefsson A. Psychiatric illness in women requesting caesarean section. BJOG, 2015;122:351-358.

II. Möller L, Josefsson A, Bladh M, Lilliecreutz C, Andolf E, Sydsjö G. Mental health after first childbirth in women requesting a caesarean section; a retrospective registerbased study. BMC Pregnancy Childbirth. 2017 Sep 29;17(1):326. doi:10.1186/s12884017-1514-2.

III. Möller L, Josefsson A, Bladh M, Lilliecreutz C, Sydsjö G. Reproduction and mode of delivery in women with vaginismus or localised provoked vestibulodynia: a Swedish register-based study. BJOG. 2015 Feb;122(3):329-34. doi:10.1111/1471-0528.12946.

IV. Möller L, Josefsson A, Lilliecreutz C, Gunnervik C, Bladh M, Sydsjö G.

Reproduction, fear of childbirth and obstetric outcomes in women treated for fear of childbirth in their first pregnancy: A historical cohort. Acta Obstet Gynecol Scand. 2018;00:1-8. https://doi.org/10.1111/aogs.13503. 


\section{List of abbreviations}

FOC - Fear of childbirth

$\mathrm{CS}$ - Caesarean section

CSMR - Caesarean section on maternal request

ANC - Antenatal care

OR - Odds ratio

aOR - Adjusted Odds ratio

IQR - Interquartile range

LPV - Localized provoked vulvodynia

MBR - Medical Birth Registry

NPR - National Patient register

TPR - Total Population Register

ICD - International Classification of Diseases

DSM - Diagnostic and Statistical Manual of Mental Disorders

SEK - Swedish Krona

BMI - Body Mass Index

NRS - Numeric rating scale

SPSS - Statistical Package for the Social Sciences 


\section{Introduction}

Fear of childbirth - Prevalence, definitions, causes and associated factors

Approximately 5-20\% of pregnant women suffer from moderate to severe fear of childbirth (FOC) (1-13). FOC is defined as primary or secondary depending on time of onset where primary FOC is manifested before first childbirth. The fear is commonly divided into mild, moderate, severe or phobic (Table 1).

Table 1. Definition of the degrees of FOC (14).

\begin{tabular}{|c|c|}
\hline Degree of FOC & Definition \\
\hline Mild FOC & $\begin{array}{l}\text { A mild worry that helps the woman to prepare for the upcoming } \\
\text { childbirth. }\end{array}$ \\
\hline Moderate FOC & $\begin{array}{l}\text { A worry that is difficult for the woman to cope with by herself and } \\
\text { requires extra support }\end{array}$ \\
\hline Severe FOC & $\begin{array}{l}\text { A major worry that may cause the woman to not dare become } \\
\text { pregnant, give birth vaginally or even cause psychiatric illness. }\end{array}$ \\
\hline $\begin{array}{l}\text { Phobic FOC } \\
\text { (Tokophobia) }\end{array}$ & $\begin{array}{l}\text { An extreme fear causing avoidance of pregnancy or vaginal childbirth. } \\
\text { For some women the fear is so intense they postpone or abort } \\
\text { pregnancies. }\end{array}$ \\
\hline
\end{tabular}

Common reasons for FOC are lack of trust in one's own ability to give birth, fear of medical interventions, a fear of losing control, of pain, birth injuries, dying, concerns for the fetus and a lack of trust in the staff $(2,15,16)$. For multiparous women, FOC is often associated with a previous negative birth experience, obstetric complications and instrumental deliveries $(4,8$, $10,12,17-20)$. For some women a previous negative experience with healthcare (21) or blood- and injection phobia are associated with FOC (22).

Several studies have investigated sociodemographic characteristics of women with FOC, but the results are conflicting. Some studies find women with FOC more often are smokers (7), more often are single or have a low social support $(4,7,8,11,12)$, have a lower $(7)$ or higher educational attainment (12), a lower maternal age, are more often unemployed $(7,23)$ and foreign born (13) compared to women without FOC. However other studies have found no differences in sociodemographic characteristics in women with or without FOC $(6,10)$. Several studies have found that women with FOC are a more psychologically vulnerable 
group in having a more anxiety-prone personality $(6,24,25)$ and more often suffer from symptoms of anxiety and depression (7, 8, 11, 18, 26-29).

For some women with FOC the fear is so intense that they wish to give birth by caesarean section (CS), a so-called CS on maternal request (CSMR) $(9,12,17,30)$. CSMRs add to the overall increase in CS worldwide (31). This reason has become the main indication for elective CS in the capital area in Sweden 2005, constituting 38.5\% of all elective CSs and $3.9 \%$ of all deliveries (32). Karlström et al found the rate of CSMR in the capital area of Sweden increased from $1.3 \%$ to $3.6 \%$ of all full-term births during the years 1997 to 2006 (33). Approximately $8 \%$ of pregnant women prefer a CS and this preference is more common in women with FOC $(9,12)$. Wiklund et al found primiparae giving birth by CSMR more often were born outside of Sweden, older, rated their health as less good, planned for one child only, attended parent education less often and more often conceived by in vitro fertilization (34).

\section{CSMR and its association to FOC}

CSMR is a CS performed in the absence of medical indications. According to Swedish healthcare law a woman can not choose a CS for herself, it is always the obstetrician's decision. The woman should be informed about the potential risks and benefits for herself and the child in the short- and long-term perspective (Table 2) as well as be offered counselling for her fear. If the woman still cannot imagine a vaginal delivery, and the reasons for the request are considerable, the obstetrician may decide on performing an CSMR (35). Therefore, in Sweden virtually all CSs coded in the diagnostic system as CSMR i.e. "CS on psychosocial indication" are because of severe FOC. In rare circumstances the obstetrician him-/herself may recommend a CSMR because of e.g. severe psychiatric illness, but it is never performed against the will of the patient.

Therefore, in our opinion CSMR might be considered a marker for severe FOC. 
Table 2. Short- and long-term risks and benefits of CS in both mother and child (35).

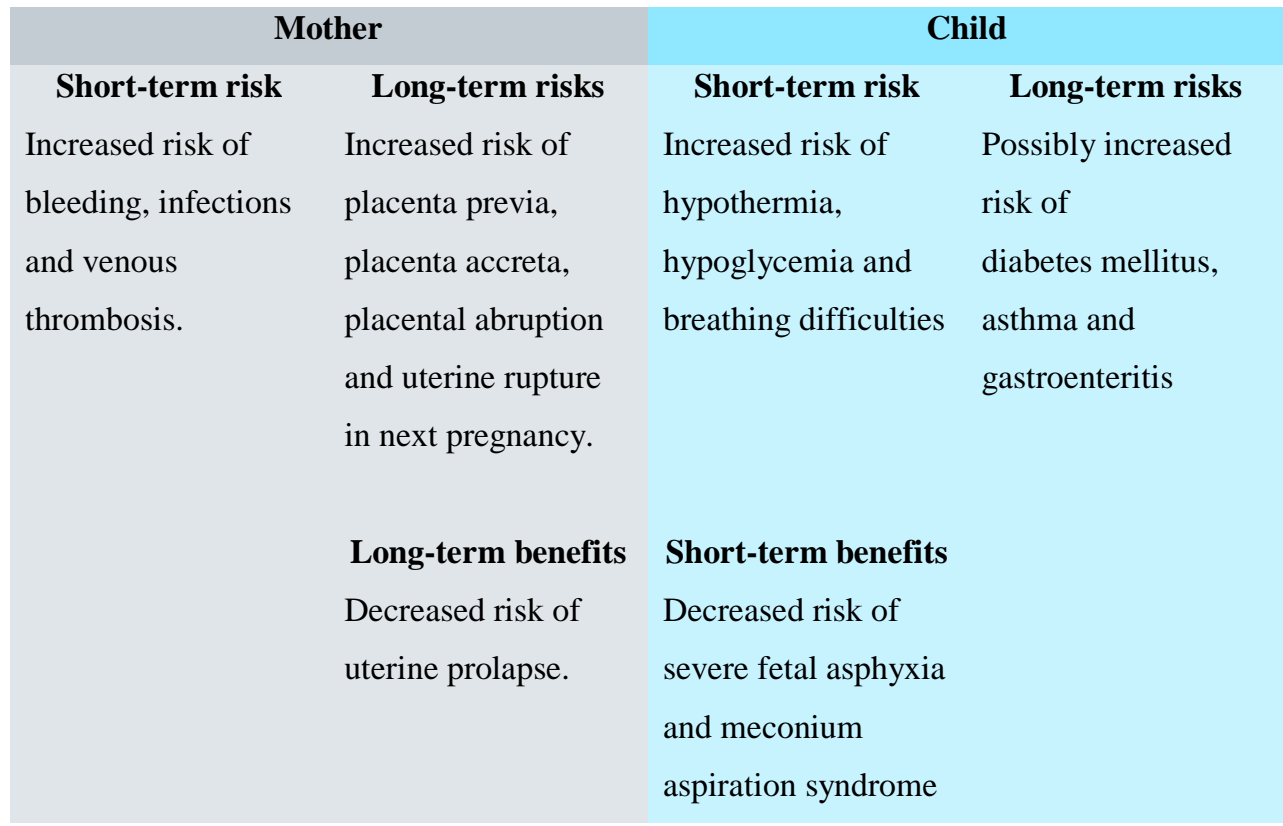

\section{Treatment for FOC}

The Swedish Society of Obstetricians and Gynecologists (SFOG) recommends in their recent report (14) that all women should be asked about their thoughts and feelings towards the upcoming childbirth at the antenatal care (ANC) clinic, preferably early in the pregnancy. Mild fear should be treated in the ANC by the midwife. Women with moderate to severe FOC should be referred to the specialist maternity care for counselling. The counselling is individualized and can be given by specialist midwives, obstetricians, psychotherapist or psychologists. Some women may be referred to a psychiatrist. Special units for treatment of FOC started at several clinics in Sweden during the 1980's and today all clinics have a special unit, but the care available differs substantially in different regions in Sweden (36). Approximately $8 \%$ of pregnant women receive counselling due to FOC. The treatment is based on psychoeducation, psychology and cognitive behavioral theory. That is, to increase the woman's knowledge about pregnancy and childbirth, teach relaxation techniques, to inform about the nature of anxiety and fear, to recognize thoughts and feelings, reevaluate and to address avoidance. Most often the woman visits the delivery ward before childbirth and a birth plan is constructed at the end of treatment. The birth plan should be reasonable, and the woman should be informed about the possibility of having to deviate from the original birth 
plan in emergency situations. For some women the birth plan constitutes a CSMR or a planned induction of labor with a promise of an early CS e.g. in case of slow progress of labor (14).

Studies have found women receiving counselling due to FOC in general are satisfied with the care given $(37,38)$. Still, in a follow-up one year after childbirth they experienced their births as less positive (37), more often wished for an elective CS (31\% vs $4 \%$ ) in future childbirths and more often considered not having any more children (19\% vs $9 \%$ ) compared to women who did not seek/received counselling for FOC during their pregnancy (37).

To decrease these women's FOC, the rate of CSMR and to promote a more positive birth experience, several treatments for FOC have been evaluated. Group psychoeducation and relaxation exercises $(39,40)$ as well as individual crisis oriented therapy $(41)$ have been shown to decrease the rate of CSMR and to more often provide a positive birth experience compared to conventional treatment. Internet based cognitive therapy has been shown feasible if the woman is motivated (42) but in a recent randomized control trial the drop-out rate in the group receiving internet based cognitive therapy was large, indicating that the woman must be motivated to adhere to the therapy (43). One study found women who had received treatment for FOC and decided to plan for a vaginal childbirth more often gave birth by emergency CS (44).

\section{Impact on reproduction}

Reproductive patterns in women with primary FOC have not been studied extensively. However, there are some indications that women with primary FOC may give birth to fewer children than women without FOC. Women with FOC who give birth by CSMR more often plan for one child only and are older at their first childbirth. Wiklund et al found women giving birth by CSMR more often had received in vitro fertilization which possibly could indicate infertility among women with FOC (34). However, these women were older than the women in the comparison group which is why further studies with comparable groups are required to be able to assess reproductive function in women with FOC. Previous studies have found women with secondary FOC have longer time periods between their pregnancies (45) and women giving birth by CS give birth to fewer children (46). Women who received counselling for FOC during pregnancy more often reported negative birth experiences and more often considered not having any more children one year after childbirth in a study by Larsson et al (37). However, these women were more often multiparous compared to the 
reference group, which could explain why these women more often considered not having any more children. These are some indications of a possibly differing reproductive pattern in women with FOC, but further studies are needed.

\section{Psychiatric disorders}

Women with FOC suffer more often from psychiatric illness. Several studies have found anxiety and depression are more prevalent among women with $\operatorname{FOC}(7,8,12,18,26,29)$. Furthermore, they differ in personality $(6,23-25)$ and more often report abuse in childhood (3, 47) and/or in healthcare settings (21). Rouhe et al found in a register-based study that women with FOC more often had received care for psychiatric disorders before and after childbirth and used psychotropic medications more often than women without FOC. The most common disorders were mood disorders and anxiety syndromes (28).

\section{Vulvodynia}

According to The International Society for the study of Vulvovaginal Disorders, vulvodynia is defined as a vulvar pain of a duration of more than three months without identifiable cause. It can be subclassified according to location (localized/generalized/mixed), onset (primary i.e. at first vaginal penetration and secondary i.e. after pain free penetration), pain-eliciting stimuli (unprovoked, provoked or mixed) and by its temporal pattern (persistent, intermittent, constant, immediate and delayed) (48) . Localized provoked vulvodynia (LPV), previously called vulvar vestibulitis syndrome, is one of the most common causes of dyspareunia. The prevalence ranges from about 6-9\% depending on the study population (49-55).

The pain is localized to the vestibule, most often at 4-8 o'clock just outside the hymenal ring. Vaginal penetration (tampon, penis, finger) causes pain that is often described as a burning, itching, raw or tearing $(56,57)$. A continuous burning pain can persist for minutes or days after vaginal penetration.

LPV is diagnosed if the woman describes localized provoked vulvar pain of a duration of $\geq 3$ months and other causes such as Candida, condyloma, other vaginal infections, dermatoses etc. are excluded.

The pathophysiology of LPV is unknown and it is considered to be a multi-factorial pain condition. Chronic pain conditions are caused by dysfunctional pain, that is pain without noxious stimuli. The proposed mechanism for acute pain transforming into chronic 
dysfunctional pain is peripheral and central sensitization and descending modulation of pain stimuli (58).

Studies have found an increased density of nerve fibers in affected vulvar tissue (59) and a lower threshold for pain in extremities which could indicate peripheral and central sensitization (60). Furthermore, other chronic pain conditions such as fibromyalgia and irritable bowel syndrome are more common in women with LPV $(51,61)$. The initiating cause is unknown. Many women with LPV report recurrent vaginal Candida infections which in a mouse model has been shown to induce allodynia and hyperplasia of nerve fibers (62). Vestibular fibroblast from women with LPV also show a greater inflammatory response to Candida Albicans compared to fibroblasts from women without vulvodynia. This proinflammatory response could contribute to the induction of pain in LPV $(63,64)$. However, the exact pathophysiology of LPV is unknown and the initiating and maintaining factors may differ between women.

These factors have been suggested to be associated with LPV;

- Polymorphism in genes regulating the inflammatory response $(65,66)$, possibly contributing to a greater inflammation that may trigger peripheral sensitization or increased susceptibility to microbes (67).

- Polymorphism in the serotonin receptor gene, 5HT-2A, with a similar distribution as in fibromyalgia patients (68). Serotonin is important for e.g. chronic pain conditions and psychiatric disorders.

- Several studies have investigated the histology of vulvar tissue in women with LPV compared to women without LPV. The results have been conflicting; some studies find an increased abundance of e.g. B-lymphocytes and evidence of germinal centers (69) but other studies have found no difference in the amount of inflammatory cells $(70,71)$.

- Many women with LPV report premorbid anxiety, mood disorders (72), PTSD (73) and sexual/physical abuse in childhood (74) why psychological factors may be important.

- About half of all women with LPV report comorbid pain conditions such as irritable bowel syndrome, fibromyalgia and interstitial cystitis $(51,61)$, which may suggest a common ground. 
- There is conflicting evidence regarding the use of oral contraceptives where some studies have found an increased risk of LPV with use of oral contraceptives, especially at a young age and with low estrogenic/high androgenic/high progestogenic profile (75), but other studies have found no increased risk (50).

- An altered pain-processing in the brain (76), higher gray matter density in painmodulatory and stress-related areas (77) as well as general allodynia to mechanical pressure as measured in the thumb (60) has been observed in women with LPV which could indicate central sensitization (78) .

Vaginismus is another cause for dyspareunia or inability to have sexual intercourse. It is defined in DSM-IV as "Recurrent or persistent involuntary spasm of the musculature of the outer third of the vagina that interferes with sexual intercourse" (79). Since there is an overlap between vaginismus and LPV $(80,81)$ the conditions are collapsed into one category in DSM-V called "genito-pelvic pain/penetration disorder" (82).

Little is known about these women's reproductive pattern, pregnancy- and childbirth outcome. Because of severe pain these women may be unable to engage in vaginal intercourse and thus suffer from involuntary childlessness $(47,48)$. A study in Israel found vaginismus was an independent risk factor for giving birth by CS (OR 7.1, 95\% CI 4.5-11.1). The primary indications for CS in women with vaginismus were difficulties in performing vaginal examinations and maternal request (83). A population-based study in USA found a tendency towards increased risk of CS among women with vulvodynia, however the results did not reach statistical significance $(30.0 \%$ vs $16.7 \%, \mathrm{p}=0.07)$. They found no difference in the rate of achieving pregnancy comparing women with vulvodynia to women with no history of vulvar pain. However in women with vulvodynia, those having limited vaginal intercourse (due to vulvodynia) and those with constant versus intermittent pain were less likely to become pregnant (84). In a qualitative study, women with vulvodynia described using strategies such as ovulation sticks to decrease the frequency of painful intercourse when trying to conceive. They also timed their efforts in conceiving to less painful periods and postponed them when the vulvar pain was worse. Some women expressed concerns about pain during childbirth which for some women meant they opted for a CSMR. Some women had been told a pregnancy and vaginal childbirth may decrease or cure their symptoms (85). We hypothesize that these women may give birth to a lesser extent and when pregnant they might have an increased risk of FOC because of fear of pain during vaginal examinations 
associated with pregnancy and childbirth, fear of worsened symptoms after a vaginal delivery as well as fear of the childbirth itself. 


\begin{abstract}
Aims
The overall objective of the studies on which this thesis is based was to investigate psychiatric- and reproductive health in women with primary FOC. In study I and II, giving birth by CSMR was used as a surrogate variable for severe primary FOC. This was considered appropriate since the primary indication for CSMR is severe FOC.

Furthermore, we hypothesized that women with LPV/vaginismus may give birth by CSMR more often. Little is known about their reproductive pattern and obstetric outcome.
\end{abstract}

The specific objectives of the studies were:

- To compare psychiatric in- and outpatient care during the five years before first childbirth in primiparae delivered by CSMR compared to all other primiparae giving birth during the same period (Paper I).

- To compare psychiatric in- and outpatient care during the five years after first childbirth in women giving birth by CSMR in their first childbirth to all other women giving birth during the same period (Paper II).

- To compare sociodemographic variables, parity, mode of delivery and childbirthrelated complications in women diagnosed with vaginismus and/or LPV before their first childbirth compared to women without a diagnosis (Paper III).

- To compare reproduction, obstetric outcomes, FOC, birth experience and treatment for FOC in women with and without FOC in their first pregnancy leading to parturition (Paper IV). 


\section{Methods}

\section{Data sources}

\section{National registers}

The Swedish Medical Birth Register (MBR) is based on data from standardized medical records during pregnancy, childbirth and perinatal care. It started in 1973 and covers about $98-99 \%$ of all pregnancies leading to parturition. It has been validated. The data are collected prospectively and provide information about sociodemographic variables, number of visits at the ANC, selected somatic and psychiatric disorders registered at the ANC, medication used during pregnancy, previous obstetric history (previous mode of delivery, abortion etc.), complications during pregnancy and childbirth, fetal presentation, multiple births, gestational age, mode of delivery, blood-loss and the use of analgesia during childbirth. The perinatal data contain information on Apgar score, fetal weight, length, head circumference, infant diagnoses and operations/procedures (86) .

The National Patient Register (NPR) has recorded hospital outpatient care since 2001 and inpatient care since 1987 (87). The NPR contains patient-related data (age, sex, personal identification number, county, municipality and parish), caregiver data (hospital, department), administrative data (date of admission and discharge, duration, elective healthcare, mode of admission and discharge), medical data (primary and additional diagnoses, external causes of injury or poisoning, procedures) and data on compulsory or voluntary psychiatric care. The diagnoses are based on the Swedish version of The International Classification of Diseases (ICD) (88). The coverage in the inpatient register is generally high with a $99 \%$ coverage of primary diagnosis and it has been shown to have a high quality with a positive predictive value of $85-95 \%$ for most diagnoses (89). For psychiatric inpatient care the coverage is lower ranging from $90.0-96.9 \%$ during the years 1997-2001. The coverage is lower in the psychiatric outpatient care with $24.3-78.8 \%$ of reported visits having a primary diagnosis during the years 2001-2007 (87).

The Total Population Register (TPR) started in 1968 and includes information on births, deaths, citizenship, family relations as well as migration and country of birth for Swedish residents born abroad (90). It is considered to have a high quality though there may be some 
over-coverage mainly because of emigration of persons born outside the Nordic countries (91).

The Causes of Death Register records information on all deceased persons registered in Sweden at the time of death since 1961 (92). From 2012 on, all persons dying in Sweden irrespective of national registration are registered. The register has a virtually complete coverage of deaths and a specific cause of death is registered in $96 \%$ of all deaths. The reported causes of deaths have been shown to have about $77 \%$ correspondence to probable causes of death according to case reports, however it depends on the underlying cause of death (93).

The Education Register records data on highest level of education. The register is updated once a year and is based on data from registers of examinees from education programs and registers of previous educational background (94).

The Multi-Generation Register is a part of the TPR that records kinship. It is made up of all persons who were born in 1932 or later and those who have been registered in Sweden, at some point, since 1961. Index persons are connected to biological parents and by this we could identify the parents of our study population (95).

\section{Medical records}

Obstetrix (C) (Siemens Healthcare) is a program for digital medical records used in most ANC clinics and Obstetric Departments in Sweden. It used in the ANC, delivery, postpartum- and perinatal care. The records contain free text but mainly standardized forms with checkboxes covering e.g. somatic disorders, mode of delivery, induction of labor etc. The data in the medical records are reported by midwives and obstetricians. Obstetrix $\odot$ was the system used in paper IV. 


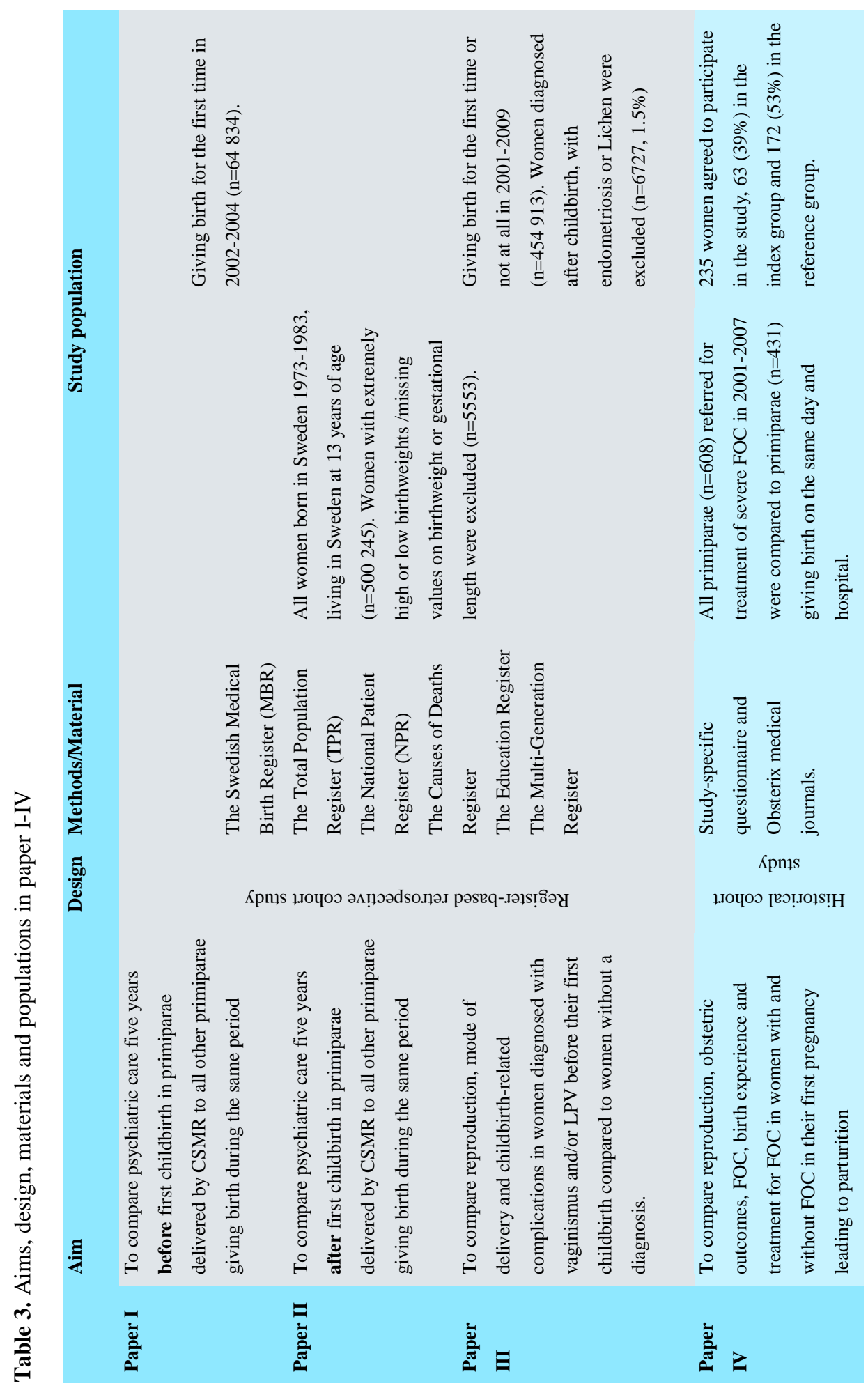




\section{Study populations and design}

Papers I-III are based on a register data on women born in Sweden, 1973-1983, alive and living in Sweden at 13 years of age and on (Table 3). All Swedish residents have a personal identification number making it possible to link data from different registers. Data from MBR, TPR, NPR, the Education register, the Multi-generation register, and The Causes of Death register were linked using the women's personal identification number. The dataset was anonymized by assigning every woman a de-identified code number.

\section{Paper I-II}

From the cohort of women born in 1973-1983 ( $n=500$ 245) we selected women giving birth for the first time during the years 2002-2004 ( $n=64$ 834). For another study using the same material, women with missing values on birthweight or gestational length were excluded $(\mathrm{n}=3360)$. Women with extremely high or low birthweights (implausible) compared with length of gestation were also excluded $(n=2193)$ (Figure 1). Women were divided into groups according to mode of delivery in first childbirth; CSMR (ICD-10 code O82.8, n=1009, 1.6\%) and other modes of delivery (vaginal, emergency CS, elective CS and instrumental vaginal childbirth), $n=63$ 847. For $128(0.2 \%)$ women the diagnosis for mode of delivery was missing, and they were therefore treated as a 'missing' group. The diagnoses for mode of delivery were based on ICD-10 and were identified as codes O80-O84 (88).

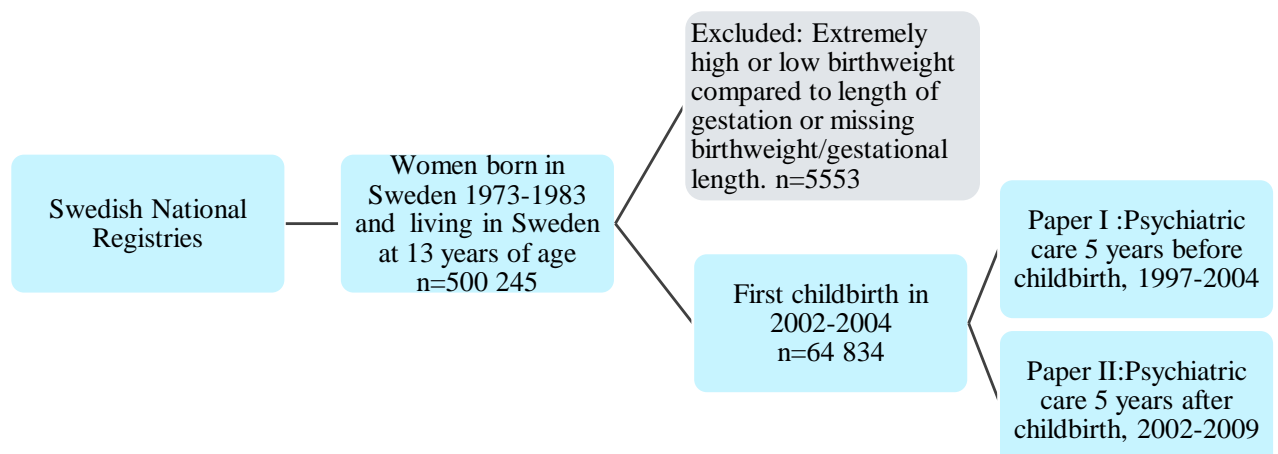

Figure 1. Study population in paper I-II. 


\section{Paper III}

Based on the same cohort as in paper I-II $(n=494692)$. The study population comprised all women born and living in Sweden at 13 years of age who gave birth for the first time or remained nulliparous during the years 2001-2009 ( $\mathrm{n}=454$ 913) (Table 3). The women were divided into two groups, one with women having been diagnosed with LPV/vaginismus during the years 2001-2009 $(n=2554,0.6 \%)$ and the other with all other women without a diagnosis $(n=445632,99.4 \%)$. The diagnoses were retrieved from NPR including both inand outpatient care. The diagnoses were based on ICD-10 and were identified as F52.5 and N94.3 for vaginismus and N76.3 for LPV (88). Women diagnosed with vaginismus/LPV after first childbirth and women with endometriosis (ICD-10 codes; N80.0-N80.9, N97.8D), lichen sclerosus (ICD-10 codes; L90.0, N90.4), lichen planus (ICD-10 code; L43.9) or lichen simplex chronicus (ICD-10 codes; L28.0) were excluded ( $n=6727,1.5 \%)$.

\section{Paper IV}

The study population consisted of all nulliparous women who attended the ANC clinic and gave birth at one University or County Hospital in the Southeast of Sweden during the years 2001-2007 (Table 3). The index group consisted of all nulliparous women who had been referred to the special units at the Departments of Obstetrics and Gynaecology for treatment of severe FOC $(n=608)$. Women who moved out of the area, who were not diagnosed as FOC and therefore not treated, gave birth at another hospital or had a late spontaneous abortion were excluded, resulting in an index group of 181 women (Figure 2). All women were assessed by the obstetrician in charge in a semi-structured interview to assess the degree of the phobia. All women were diagnosed with severe FOC according to DSM-IV (79); severe phobia with features of both physical and emotional signs such as avoidance, strong fear, anxiety and panic. The women received individualized treatment based on psychology (to explain the features of anxiety and panic), psychoeducation (to assess the woman's knowledge of childbirth and to teach relaxation techniques) and cognitive behavioral theory (to assess feelings, thoughts, avoidance and to alter reactions). The counselling was given by midwives, obstetricians or psychologists depending on the needs of the woman. Many of the women also made a visit to the labor ward before childbirth. All other nulliparous women giving birth on the same day and at the same hospital were used for reference $(n=431)$. None 
of the women in the reference group had any contact with the Department of Obstetrics and Gynaecology because of FOC during their first pregnancy (96).

Women not fluent in Swedish or where no current address was found were excluded $(n=128)$ which is why 161 women in the index group and 323 women in the reference group were invited to participate in the study (Figure 2).

The women were contacted by letter in 2015, i.e. 7-14 years after first childbirth and asked to participate in a study regarding health, reproduction and FOC. Participation was voluntary. All women were asked to sign a consent form for access to their medical records and to fill out a study-specific questionnaire. The questionnaire and consent form were returned in a prepaid envelope. Two reminders were sent out, one after two weeks and one after six weeks. All study participants were sent two scratch able lottery tickets at a value of 50 SEK. The questionnaire comprised of 21 questions regarding sociodemographic data, current and previous somatic- and psychiatric health, childbirths, complications during and after pregnancy and childbirth, birth experience and FOC today. 235 women agreed to participate in the study, 63 (39\%) women in the index group and 172 (53\%) in the reference group (Figure 2). 227 (96.6\%) women provided written consent for access to their medical records and 213 women filled out the questionnaire. 


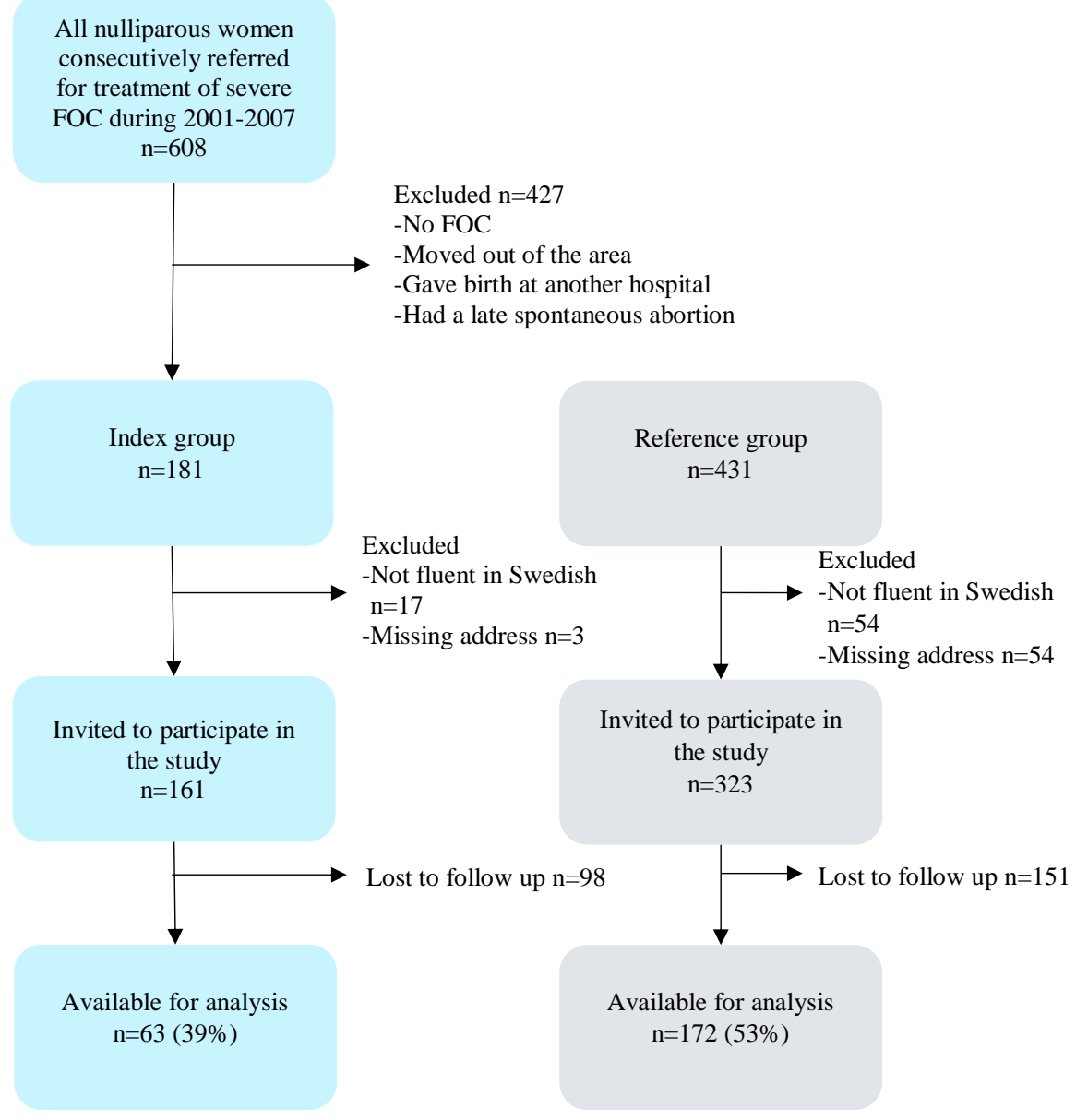

Figure 2. Flow-chart of exclusion and lost to follow up of study participants in paper IV. 


\section{Main outcome measures}

\section{Paper I-II}

In paper I the exposure of interest was psychiatric in- and outpatient care during the five years before childbirth (1997-2004). This was defined as any psychiatric diagnosis during a period of five years before the date of first childbirth in the NPR. The time was determined by subtracting five years from the date of childbirth and then searching for date of admission or date of visit registered together with a psychiatric diagnosis. The diagnoses are based on the Swedish version of the ICD from the World Health Organization (88). In 1997 the healthcare system changed the ICD version used from ICD-9 to ICD-10. During this year, ICD-9 and ICD-10 were used interchangeably. Psychiatric diagnoses in ICD-9 and ICD-10 were identified as codes 290-319 and F00-F99, respectively $(88,97)$. Therefore, we searched for both ICD-9 and -10 codes in 1997 and only for ICD-10 codes in 1998-2004. ICD-9 codes were translated to ICD-10 using a conversion table (97). Psychiatric disorders were divided into 11 categories according to ICD-10 (88) (Figure 3).

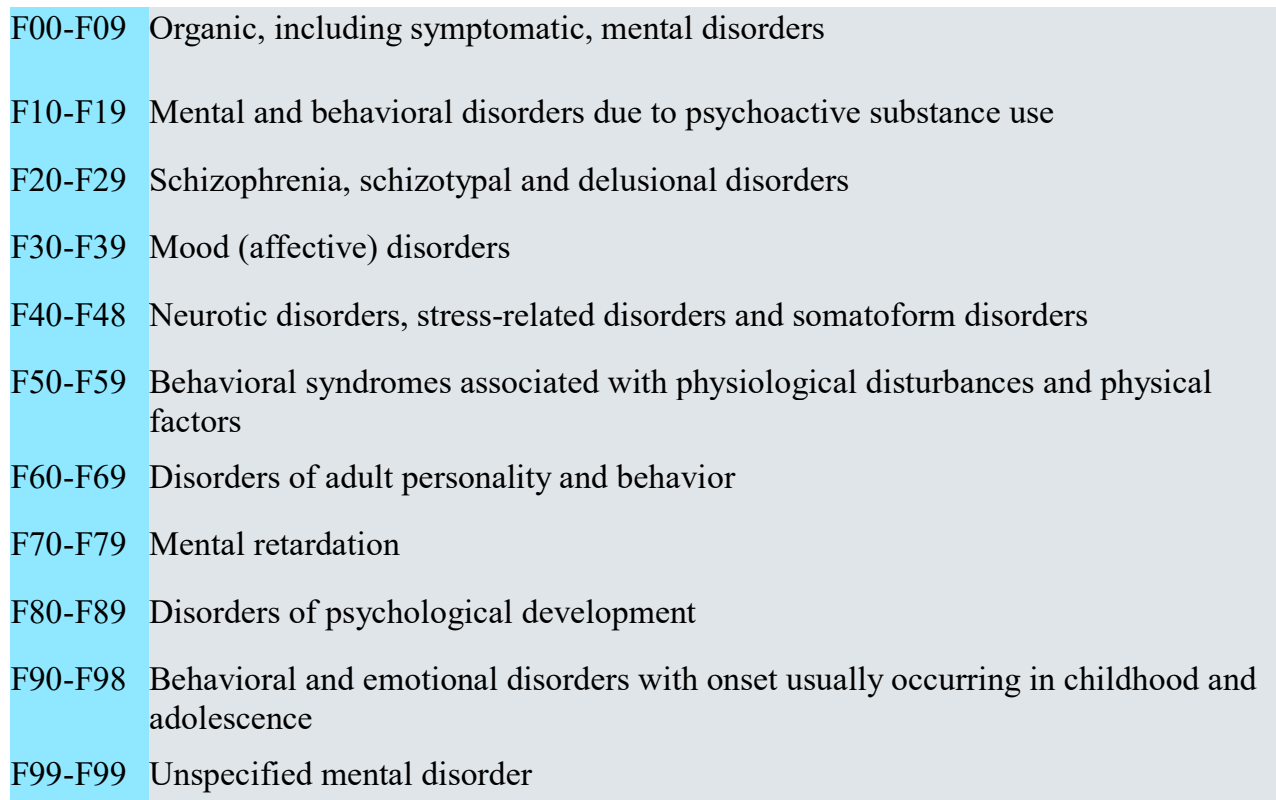

Figure 3. Categories of mental disorders according to ICD-10. 
For paper II psychiatric disorders five years after first childbirth (2002-2009) were retrieved. During these years, only ICD-10 was used and therefore we searched for the same codes as above stated (F00-F99) (Figure 3).

The following background variables were registered at admission to antenatal care: age, body mass index (BMI), tobacco use, and somatic diseases registered at the ANC clinic (recurring urinary tract infection, inflammatory bowel disease, epilepsy, asthma/lung disease, diabetes mellitus, kidney disease, hypertension and systemic lupus erythematosus). Age at first childbirth was categorized into $<25$ or $\geq 25$ years old. BMI was divided into five categories $\left(<18.5,18.5-24.9,25-29.9,30-34.9\right.$, and $\left.\geq 35 \mathrm{~kg} / \mathrm{m}^{2}\right)$. From the other registers we gathered information on parents' country of birth, the women's marital status (married, unmarried or divorced/widowed), highest level of education (elementary, high school or university), and working status in 2004. Parents' country of birth was categorized as born in or outside of Scandinavia. According to Statistics Sweden's definition of paid work in 2004, income $\geq 39300$ SEK per year was defined as employed and <39 300 SEK was defined as unemployed. 


\section{Paper III}

Main outcome measures were sociodemographic data, parity defined as having given birth during the years 2001-2009, mode of delivery and complications during childbirth. Marital status was based on data from TPR and was categorized into married, unmarried or divorced/widowed. Educational attainment was defined as highest level of education in 2006 (elementary, high school or university), registered in the Education register. Body mass index (BMI) was divided into five categories ( $\left.<18.5 ; 18.5-24.9 ; 25.0-29.9 ; 30.0-34.9 ; \geq 35 \mathrm{~kg} / \mathrm{m}^{2}\right)$. Because all women were born in Sweden, parents' country of birth was retrieved using the Multi-generation register to identify the parents of our study population and TPR to define country of birth as in or outside of Scandinavia. Employment was defined according to Statistics Sweden's definition as a yearly income $\geq 39700$ SEK in the year 2006. BMI and tobacco use (including smoking and the use of snuff) during pregnancy were only available for women giving birth during the study period.

Mode of delivery and complications during pregnancy and childbirth were based on ICD-10 diagnosis codes in MBR; O80-O84 and O60-O75 (Figure 4) respectively (88).

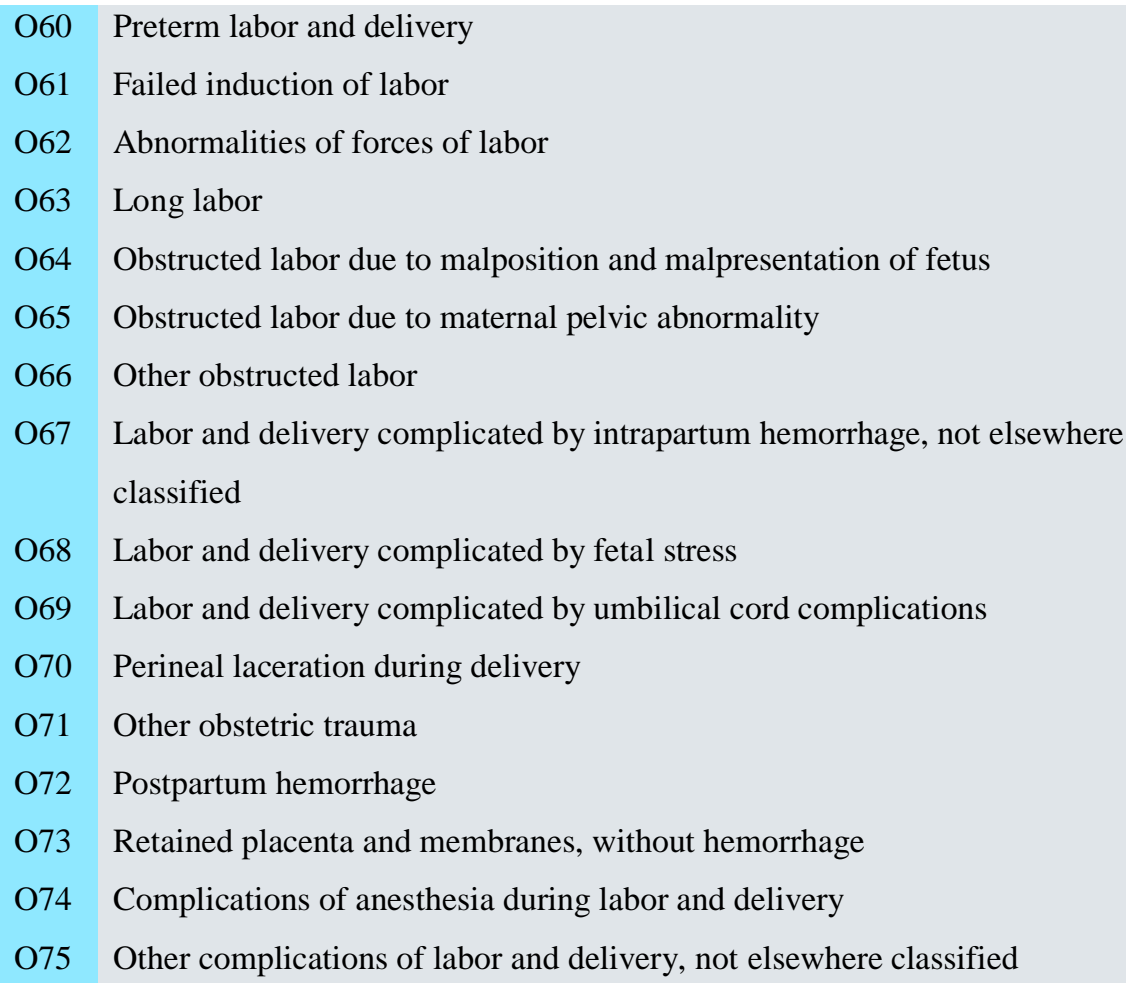

Figure 4. Complications of labor and delivery according to ICD-10. 


\section{Paper IV}

The medical records were reviewed, and the data were entered manually into a dataset where every woman was assigned a de-identified code number. These variables were retrieved; date of childbirth, infertility treatment, gestational week, induction of labor, psychiatric disorders registered at the ANC clinic, complications during pregnancy and childbirth, counselling for FOC and mode of delivery.

Main outcome measures were number of childbirths at data collection (in 2015), complications during pregnancies and childbirths, mode of delivery, current FOC, counselling for FOC after first childbirth and birth experience.

The number of childbirths was based on data from the medical records. Eight women $(0.4 \%)$ did not consent to accessing their medical records but all had provided data regarding the number of childbirths and six women had also provided data regarding mode of delivery in the questionnaire. Women with twin births (five women in their first pregnancy and one in her second) were excluded from analysis of number of childbirths. For two women in the reference group and one in the index group we were unable to retrieve medical records from their second pregnancy and childbirth due to giving birth in another county which did not provide access.

FOC and birth experience were assessed in the questionnaire. The questions were phrased as; “Imagine you are pregnant today. Do you experience any fear towards the delivery?" and "How did you experience your delivery/deliveries?". The women graded their fear on a 0-10 point numeric rating scale (NRS) where 0 represented "no fear at all" and 10 "the worst imaginable fear". An NRS $\geq 9$ was considered severe FOC. Birth experience was likewise assessed for each childbirth separately by a NRS of 0-10 where 0 represented "very negatively" and 10 "very positively".

Counselling for FOC after first childbirth was defined as registered counselling for FOC in the medical records from the ANC in subsequent pregnancies and/or self-reported counselling for FOC after first childbirth as reported in the questionnaire.

Complications during pregnancy and childbirth were defined as diagnoses reported in the medical records. The following complications were reported; preeclampsia including HELLPsyndrome, gestational hypertension, threatening fetal asphyxia, post-partum hemorrhage $\geq 1000 \mathrm{ml}$, perineal laceration degree 3-4, disproportion and slow progression of labor. Gestational week was retrieved from the medical records. 
Background data (age, tobacco use, marital status, working status and country of birth) were based on data from the questionnaire and therefore in 2015. Infertility treatment and psychiatric health were based on combined data from the questionnaire and medical records. Previous and current psychiatric health were assessed in the questionnaire by the question; "Have you ever been diagnosed with a psychiatric disorder?". The women were asked to fill prespecified checkboxes on common diagnoses or to fill out their diagnoses in plain text. For women who did not answer the question in the questionnaire, data were retrieved from the medical records in the ANC clinic.

\section{Statistics}

\section{Paper I}

Women giving birth by CSMR were compared to all other women giving birth during the same period. Pearson's Chi-square test was used to test for univariate statistical differences in socio-demographic variables and psychiatric disorders between the two groups. Multiple logistic regression was used to estimate the risk of CSMR using somatic disease, psychiatric disorders as well as socio-demographic variables as predictors.

\section{Paper II}

Women giving birth by CSMR were compared to all other women giving birth during the study period (reference group). The prevalence of any psychiatric disorder, specific categories of psychiatric disorders (Figure 3) as well as the distribution of in- and outpatient psychiatric care was compared across the two groups by Pearson's Chi-Square test. When $\geq 20 \%$ of the expected values were below five, Fisher's Exact test was used instead.

New cases, i.e. women who only had been diagnosed with a psychiatric disorder after first childbirth, were compared using Pearson's Chi-square.

Paired T-tests was used to test for statistical differences in the prevalence of psychiatric disorders five years before and five years after childbirth within each group (CSMR and other modes of delivery).

The risk of psychiatric disorders after first childbirth was estimated by multiple logistic regression using psychiatric disorders after childbirth as the outcome and CSMR, sociodemographic variables (age, BMI, educational attainment, tobacco use, marital status, parents' country of birth, working status and somatic diseases) and psychiatric disorders before 
childbirth as covariates. CSMR and previous psychiatric care was tested for interaction effect in the logistic regression model. No significant interaction effect was found. A sensitivity analysis where we excluded all women who were diagnosed with a psychiatric disorder before childbirth was performed and no significant differences were found.

\section{Paper III}

We compared women with vaginismus/LPV to women without a diagnosis (controls). Person's Chi-square test were used to calculate univariate statistical differences. By multinomial regression, using vaginismus/LPV and sociodemographic characteristics as explanatory variables we could estimate the risk of different modes of delivery. The odds of giving birth was calculated by logistic regression. In the adjusted analysis working status, educational level and marital status were set as predictors. These covariates were chosen as they differed significantly between women with LPV/vaginismus and controls. Logistic regression was also used to calculate the risk of complications and birth injuries during labor and childbirth. Sociodemographic factors, birthweight $>4000 \mathrm{~g}$, mode of delivery and vaginismus/LPV were used as predictors. We used these covariates as they could possibly independently impact the risk.

To avoid bias by exclusion we performed a sensitivity analysis where we included all previously excluded women who were diagnosed after childbirth and compared the rate of childbirth. The sensitivity analysis did not alter the results significantly thereby indicating that exclusion was not a source of bias.

\section{Paper IV}

Women in the index group were compared to the reference group. Univariate statistical differences in categorical sociodemographic variables were compared using Pearson's Chisquare test. Whenever $\geq 20 \%$ of the expected values were below five, Fishers exact test was used instead. The numerical variable age was non-normally distributed and was therefore compared using Mann-Whitney $U$ test as was the ordinal variable birth experience. Drop-outs and participants were compared within each group by Pearson's Chi-square test.

All statistical analyses were carried out in SPSS (versions 19, 20, 22 and 24 respectively) (IBM, SPSS, Inc., Armonk, NY, USA). A p-value below 0.05 was considered statistically significant. 


\section{Ethical considerations}

The Regional Ethical Board at Linköping University approved all studies. \#2011-246-31.2008-08-10.

M 204-8.2008-11-12.

171-31. 2014-05-22.

The material in paper I-III was based on data from several National Health Registers. The data is provided by the National Board of Health and Welfare and Statistics Sweden. To access the data, one must have approval from an Ethical Board as well as approval for the study from the agencies themselves. Since the data is anonymized, individual consent is not required. Therefore, it is important to present the data in a way that personal identification is not possible.

Our National Registers in general have a good coverage and are valid. They are invaluable resources for research in cases were other study designs are not possible. E.g. when a randomized controlled trial cannot be considered ethical.

In our studies, the data were aggregated, and all women were de-identified by a code number. Personal identification was not possible.

In paper IV data were retrieved from medical records and a questionnaire. All subjects whose medical records were reviewed had provided signed consent for accessing their medical records. The data from the medical records were anonymized by assigning every woman with a de-identified code number. Participation in the study was voluntary. However, one must consider the potential effect of receiving an invitation-letter regarding a study on pregnancy and childbirth in women with severe FOC and possible previous traumatic experiences in childbirth and pregnancy. This may evoke traumatic memories and cause distress. Indeed, some women promptly answered that they did not want to participate or receive further information about the study, which of course was respected.

We found it important to conduct the study to learn more about these women's experiences with the long-term aim of providing a better experience and outcome. This information is impossible to receive without involving the women. Therefor we considered that the potential benefits of the study outweighed the risks. 


\section{Summary of results}

\section{Paper I}

Univariate statistical analyses found women giving birth by CSMR were older, used tobacco more often, had a lower educational attainment, were more often unemployed, had a higher BMI and more often had parents born outside of Scandinavia $(\mathrm{p}<0.05)$. Furthermore, they had more often a somatic disease recorded in $\operatorname{MBR}(n=356,35.3 \%$ vs $n=16374,25.7 \%$, $p<0.001)$. One or more psychiatric disorders before first childbirth was significantly more common in women giving birth by CSMR ( $\mathrm{n}=101,10.0 \%$ vs $\mathrm{n}=2215,3.5 \%, \mathrm{p}<0.001)$. The most common disorders were "Neurotic disorders, stress-related and somatoform disorders" ( $n=60,5.9 \%$ vs $\mathrm{n}=999,1.6 \%, \mathrm{p}<0.001)$, "Mood disorders" $(\mathrm{n}=34,3.4 \%$ vs $\mathrm{n}=691,1.1 \%, \mathrm{p}<0.001)$ and "Mental and behavior disorder caused by use of psychoactive substances" ( $\mathrm{n}=21,2.1 \% \mathrm{vs}$ $\mathrm{n}=570,0.9 \%, \mathrm{p}<0.001$ ) (Figure 4). In multivariate analyses, adjusted for socio-demographic factors as well as somatic disorders registered in MBR, one or more psychiatric disorder before childbirth increased the risk of giving birth by CSMR (aOR 2.5, 95\% CI 2.0-3.2). All psychiatric disorders except "Mental retardation", "Schizophrenia, schizotypal, and delusional disorders" and "Disorders of psychological development" increased the risk of giving birth by CSMR.

\section{Paper II}

In total, $2316(3.6 \%)$ had been diagnosed during the five years before and $3607(5.6 \%)$ had been diagnosed with one or more psychiatric disorder during the five years after first childbirth. For 892 women a diagnosis was found both in the psychiatric in- and outpatient care. Women in the reference group (other modes of delivery than CSMR) were more often only diagnosed in the outpatient care $(n=1895,54.2 \%$ vs $n=51,45.1 \%)$, however this finding was non-significant; $\mathrm{p}=0.056$. The majority $(75.3 \%)$ of the women receiving psychiatric care after delivery were only diagnosed after first childbirth. This was more common in the reference group $(n=68,60 \%$ vs $n=2647,76 \%, p<0.001)$.

The prevalence of psychiatric disorders increased after first childbirth $(n=2316,3.6 \%$ vs $\mathrm{n}=3607,5.6 \%$, mean difference $0.2 \pm 0.25,95 \%$ CI $0.018-0.022, \mathrm{p}<0.001)$. The prevalence had increased in both women who had given birth by CSMR and the reference group 
$(\mathrm{n}=2215,3.5 \%$ vs. $\mathrm{n}=3494,5.5 \%$, mean difference $0.02 \pm 0.25,95 \%$ CI $0.018-0.022$, $\mathrm{t}=20.250, \mathrm{p}<0.001)$ but was non-significant in the CSMR-group $(\mathrm{n}=101,10.0 \%$ vs $\mathrm{n}=113$, 11.2\%, mean difference $0.01 \pm 0.35,95 \%$ CI $-0.010: 0.034, t=1.078, \mathrm{p}=0.281)$ (Figure 4). Having been diagnosed with any psychiatric disorder during the five years after first childbirth was more common in women who had given birth by CSMR ( $\mathrm{n}=113,11.2 \%$ vs. $\mathrm{n}=3494,5.5 \%$, $\mathrm{p}<0.001)$. Giving birth by CSMR was associated with a significantly increased risk of psychiatric illness after childbirth (aOR 1.5, 95\% CI 1.2-1.9), adjusted for background variables (age, BMI, educational attainment, tobacco use, marital status, parents' country of birth, working status and somatic diseases) and previous psychiatric care. CSMR in first childbirth increased the risk of the following categories of psychiatric disorders; "Mental and behavioral disorder due to psychoactive substance use" (aOR 2.0, 95\% CI 1.3-3.1), "Neurotic, stress-related and somatoform disorders" (aOR 1.6, 95\% CI 1.2-2.1), "Mood disorders" (aOR 1.7, 95\% CI 1.3-2.2) and "Unspecified mental disorder" (aOR 4.0, 95\% CI $1.2-13.8)$.

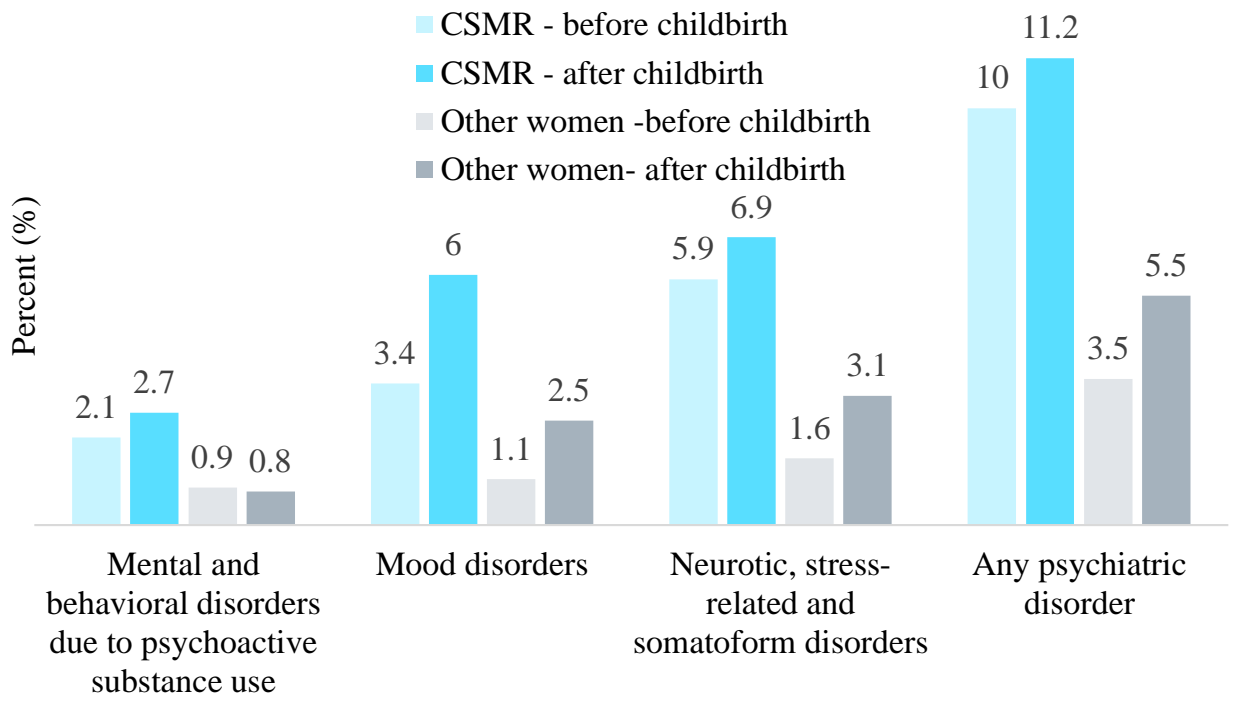

Figure 4. Prevalence (\%) of psychiatric disorders before and after childbirth in women giving birth by CSMR or other modes of delivery. 


\section{Paper III}

In total, $2554(0.6 \%)$ women were diagnosed with LPV/vaginismus before first childbirth during the study period. A total of 220 women were diagnosed with both LPV and vaginismus. Women with LPV/vaginismus had a lower BMI $(\mathrm{p}<0.001)$, a higher level of education ( $\mathrm{p}<0.001$ ), were more often 24-29 years old at first childbirth $(\mathrm{p}=0.04)$, used tobacco during pregnancy more often $(\mathrm{p}=0.008)$ and were more often unemployed $(\mathrm{p}=0.012)$ compared to women without LPV/vaginismus. Women with vaginismus/LPV were more often nulliparous $(n=1542,60.4 \%$ vs $n=220866,49.6 \%, p<0.001)$. In multivariate analysis adjusted for highest level of education, working status and marital status, women with LPV/vaginismus were significantly less likely to be parous at the end of the study period (aOR 0.61, 95\% CI 0.56-0.67). The risk of different modes of delivery (Table 4) was estimated in a multivariate analysis adjusted for sociodemographic variables where mode of delivery was considered the outcome and LPV/vaginismus the exposure. Women with LPV/vaginismus had a somewhat increased risk of giving birth by instrumental vaginal delivery (aOR 1.31, 95\% CI 1.08-1.59), emergency CS (aOR 1.28, 95\% CI 1.02-1.61) and elective CS (aOR 1.31, 95\% CI 1.01-1.70). The risk of giving birth by CSMR (aOR 3.20, 95\% CI 2.25-4.54) was significantly higher in women with LPV/vaginismus. We also found these women had an increased risk of perineal lacerations (degree 1 to 4 ) after adjustment for mode of delivery, birthweight $>4000 \mathrm{~g}$ and sociodemographic variables (aOR 1.87, 95\% CI 1.56-2.25). When comparing LPV and vaginismus separately the prevalence was significantly higher only in women diagnosed with vaginismus but not in women with LPV (Figure 5). The increased risk for perineal laceration involving the anal sphincter (degree 3-4) in women with vaginismus was significant (aOR 2.4, 95\% CI 1.5-3.6) also after adjustment for sociodemographic factors (maternal age, BMI, educational level, working status, tobacco use during pregnancy and marital status), birthweight $>4000 \mathrm{~g}$ and mode of delivery. We found no difference in the rate of other complications during pregnancy and childbirth or in the use of pain-relieving methods (spinal, infiltrative and epidural anesthesia, pethidine, paracervical and pudendal block) during labor. 
Table 4. Mode of delivery in women with LPV/vaginismus compared to women without LPV/vaginismus.

\begin{tabular}{|c|c|c|c|}
\hline Mode of delivery & Vaginismus/LPV n (\%) & Controls n (\%) & P-value \\
\hline & & & $<0.001$ \\
\hline Vaginal & $654(64.6)$ & $160252(71.3)$ & \\
\hline Instrumental vaginal & $138(13.6)$ & 26270 (11.7) & \\
\hline Emergency CS & $95(9.4)$ & $19622(8.7)$ & \\
\hline Elective CS & $83(8.2)$ & $14802(6.6)$ & \\
\hline CSMR & $40(4.0)$ & $3387(1.5)$ & \\
\hline Missing & $2(0.2)$ & $433(0.2)$ & \\
\hline
\end{tabular}




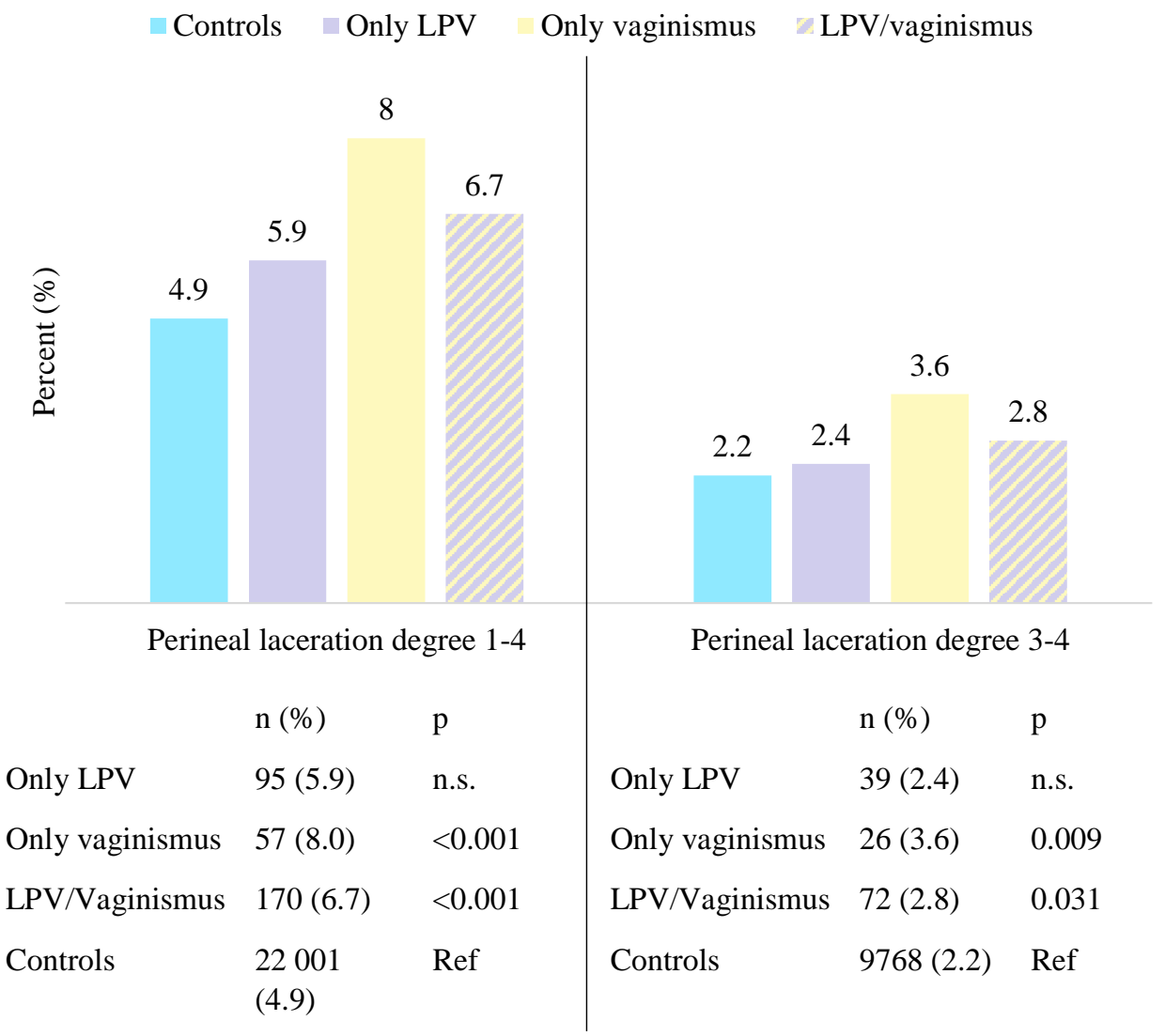

Figure 5. Prevalence of perineal lacerations degree 1-4 and only degree 3-4 i.e. involving the anal sphincter, n (\%), in women with only vaginismus and only LPV separately and collapsed into one category (including only LPV, only vaginismus and both LPV and vaginismus) compared to women without LPV or vaginismus 


\section{Paper IV}

Women treated for FOC in their first childbirth more often experienced FOC 7-14 years after first childbirth ( $\mathrm{n}=11,18.0 \%$ vs $\mathrm{n}=8,5.3 \%, \mathrm{p}=0.003)$. These women more often gave birth by $\mathrm{CS}$ in their first and second childbirth (Table 5). Women in the index group less often gave birth more than twice ( $\mathrm{n}=5,8.2 \%$ vs. $\mathrm{n}=37,22.0 \%, \mathrm{p}=0.017$ ) (Figure 6). There was no difference in the rate of complications during pregnancy and childbirth among the two groups. Women treated for FOC reported less positive birth experiences in their first pregnancy (median 6.0, IQR 6 vs 7.0, IQR 5, $\mathrm{p}=0.004$ ) and many of the women ( $\mathrm{n}=27,58.7 \%$ vs $\mathrm{n}=17$, $12.5 \% \mathrm{p}<0.001)$ received treatment for FOC in their subsequent pregnancies, irrespective of previous mode of delivery. The life-time prevalence of psychiatric disorders was higher among women treated for FOC in their first pregnancy ( $47.6 \%$ vs $14.0 \%, \mathrm{p}<0.001$ ).

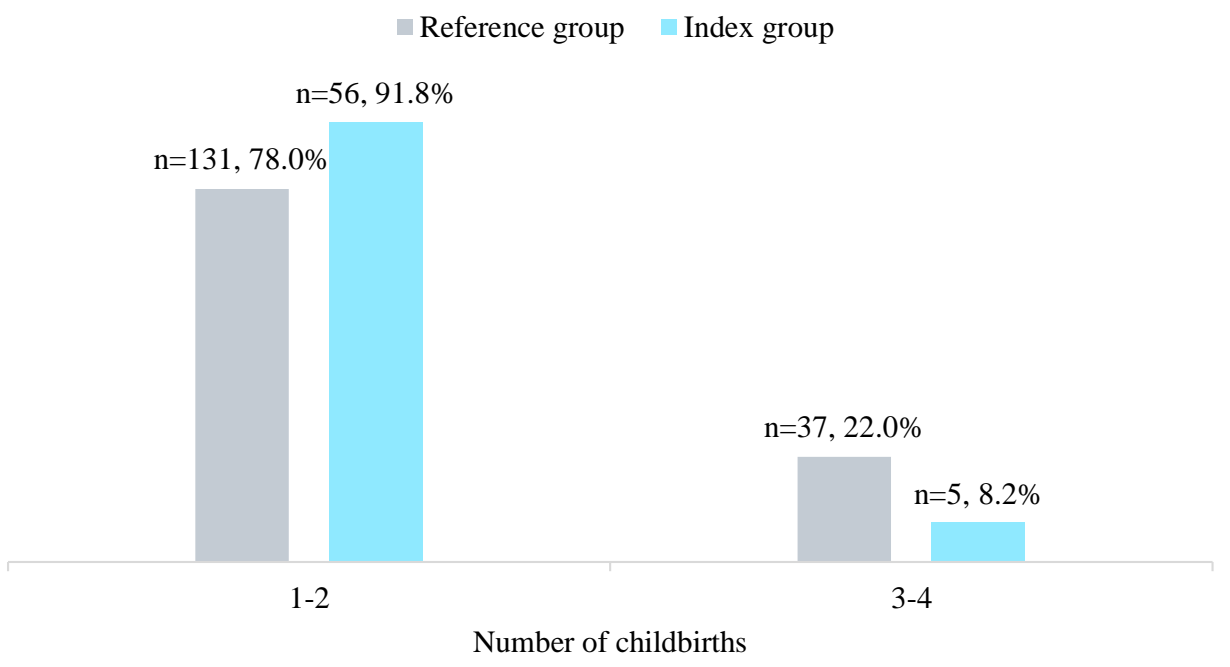

Figure 6. Number of childbirths during the study period in the index- and reference group. Women with twin births excluded. 

- क्ष

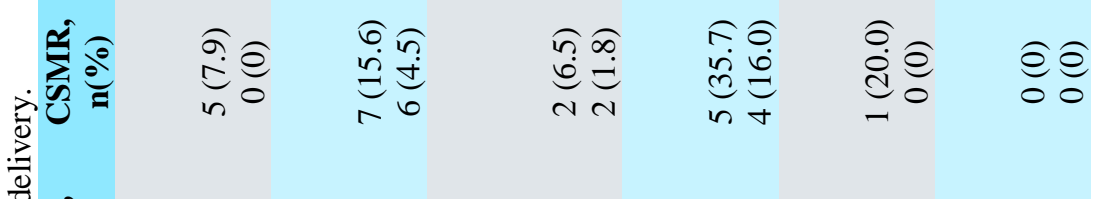

ㅎํㅇ

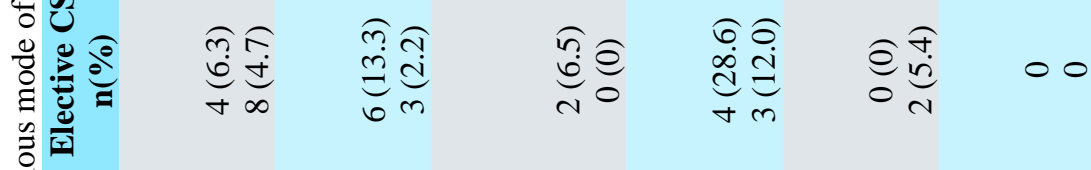

ए.

\%

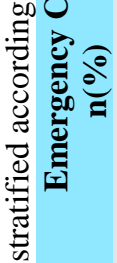

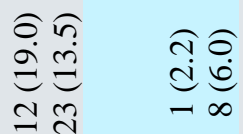

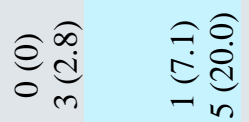

$\underbrace{\stackrel{\imath}{\infty}}_{0} \underbrace{\infty}_{m} \quad 00$

譶

하의

(1)

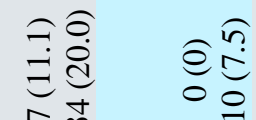

$\underset{0}{\stackrel{\infty}{=}}$

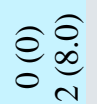

อิ

00

टे

:

4

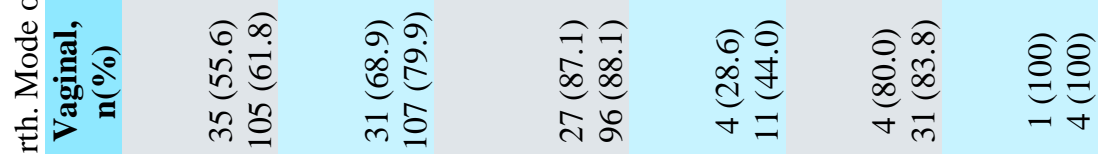

:를

苨

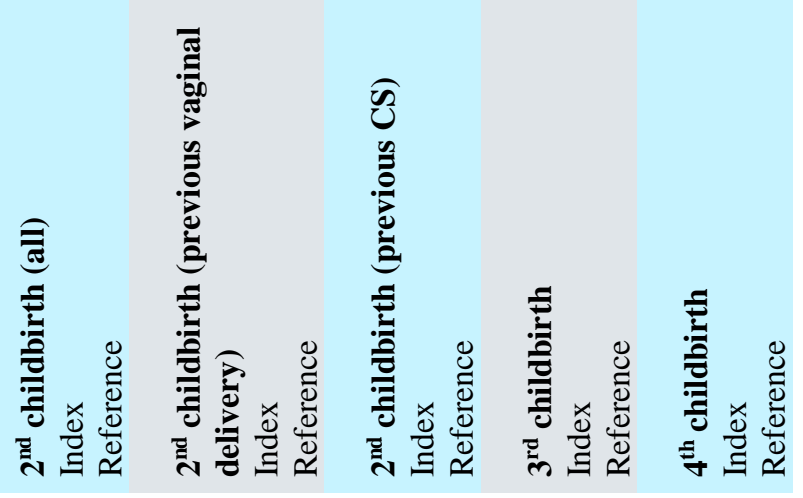




\section{Discussion}

\section{Main findings}

Primary FOC and psychiatric disorders

Women giving birth by CSMR in their first childbirth, i.e. women with severe FOC, more often suffer from psychiatric disorders both before and after first childbirth. In the study for paper I we found psychiatric disorders five years before first childbirth is a risk factor for giving birth by CSMR. In the study for paper II we were able to show that the prevalence of psychiatric disorders remains high after childbirth among women who give birth by CSMR. The overall prevalence of psychiatric disorders had increased after childbirth compared to before first childbirth however the increase was not statistically significant in women giving birth by CSMR. These women were more likely to have been diagnosed before childbirth. This could indicate these women are diagnosed and treated earlier or suffer from more severe psychiatric illness that develop earlier and are relapsing in nature.

\section{LPV/vaginismus and childbirth}

Women diagnosed with LPV/vaginismus before first childbirth were shown to have an increased risk of nulliparity during the study period compared to women without such diagnosis. When giving birth they had an increased risk of giving birth by CS, especially CSMR and when giving birth vaginally they had an increased risk of perineal laceration degree 1-4. Women diagnosed with vaginismus had a small, but statistically significant, increased risk of perineal laceration involving the anal sphincter (degree 3-4), but this was not observed in women diagnosed with only LPV. The use of pain-reliving methods was similar in the two groups.

\section{Long term outcome after counselling for FOC}

Women who received counselling for FOC in their first pregnancy seemed to more often give birth by CS in their first and second childbirths. However, there were very few women available for analysis in second childbirth which is why the results should be interpreted with caution. Despite having received counselling in their first pregnancy and being exposed to a previous childbirth many women $(n=27,58.7 \%$ vs $n=17,12.5 \% \mathrm{p}<0.001)$ received counselling for FOC in their subsequent pregnancies. Though rating their birth experience as 
less positive in their first childbirth there was no difference in the rate of having a second childbirth, however there were fewer women in the index group who gave birth more than twice. Positively we found no significant difference in the rate of complications during pregnancy and childbirth, however the study suffered from low power due to a high drop-out rate why there may be actual differences in complications that we were unable to find. Many women did not experience FOC after the childbearing years. However, a sizable proportion of women receiving counselling for FOC in their first pregnancy still experienced severe FOC (18.0\% vs 5.3\%) despite given counselling and exposure to childbirth.

\section{Methodological considerations}

Paper I-III are based on a large population-based cohort with prospectively collected data. This is a major strength because of the large study population and that diagnoses are based on data from medical records and thereby considered reliable. However, these large study populations may also cause a problem by making very small differences become statistically significant although they may not be clinically significant.

In using registers, one must consider the quality of the register. The registers used had, in general, a high quality and have been validated $(86,87,89,90-95)$. However, there are some shortcomings that may have affected our results.

The NPR was the source of psychiatric diagnoses before and after childbirth. The NPR started reporting outpatient care in 2001 (87), therefore we only covered psychiatric outpatient care during one to three years before childbirth in paper I. This has implications for our results especially in the comparison of the prevalence of psychiatric disorders after compared to before childbirth as the prevalence had increased (paper II). Therefore, the observed increase might only reflect the increased coverage and reporting from the outpatient care. This is a flaw in our study that must be considered when interpreting the results. Also, the coverage of psychiatric disorders in the NPR is generally lower than for other disorders (87). Therefore, our estimated prevalence is probably an underestimation of the overall prevalence of psychiatric disorders.

We used ICD-10 code O82.8 "CS on psychosocial indication" as the definition of CSMR. This is the diagnosis code that should be applied for CSMR (88), but we do not know whether the woman requested a CS. However, in practice this is the diagnosis code applied in severe FOC after request for a CS. 
We find CS on psychosocial indication as being the most appropriate definition and considered it important to differentiate from other indications for elective CS since many of these are medical indications and do not have an association to FOC. In our studies we use CSMR as a proxy for severe FOC since we did not measure the FOC in these women. In general, all these women suffer from severe FOC but there may be some exceptions such as e.g. severe psychiatric disorder where the obstetrician recommends a CS on psychosocial indication. These cases are presumed to be so rare it should not bias our results.

The cohort only included women born and living in Sweden at 13 years of age which lowers the generalizability. Foreign born women more often suffer from FOC (13) and this was reflected in our study where women giving birth by CSMR more often had parents born outside of Scandinavia.

The cohort is historical, including women born in 1973-1983 who gave birth in 2002-2004. Both psychiatric and maternal care may differ today as compared to that time. In Sweden the inpatient care has been decreased in favor for increased outpatient care which may affect the degree of in- versus outpatient care. The women were offered counselling for FOC in 20022004, the indications for CSMR nor recommendations for counselling has not been changed since then. However, the general knowledge in FOC is increasing and maybe women continuously receive better support and are identified in the ANC more often as time passes. However, these potential differences are unlikely to impact the observed difference in the rate of psychiatric disorders among the two groups. The absolute difference or rate of e.g. psychiatric disorders may differ today as the prevalence of psychiatric disorders seem to be increasing, at least in children and young adults in Sweden (98).

In paper II we did not investigate further reproduction after first childbirth. Many of the women in our study population will probably have given birth again during the five years after first delivery. Childbirth is a recognized risk factor for postpartum onset of psychiatric disorders, although the risk seems to be lower in the second childbirth compared to first (99). The rate of giving birth again during the five years after first childbirth may differ between women with and without FOC, this is a possible confounder. E.g. if one hypothesizes the women in the reference group more often gave birth again during the study period the increased prevalence of psychiatric disorders in this group could possibly be explained by the increased risk of psychiatric disorders associated with childbirth. 
In the study for paper III we found a very low prevalence of LPV/Vaginismus $(0.6 \%)$ which probably reflects the resistance to seeking medical attention for these disorders. Furthermore, one study found only $48 \%$ of women seeking healthcare for vulvodynia (defined as provoked vulvodynia preventing or limiting intercourse during the last six months) received a diagnosis (54). Since the outpatient care started reporting first in 2001, we excluded women giving birth before 2001. However, the coverage of the outpatient care was lower in the beginning and therefore some women may be misclassified as controls which makes us underestimate differences as well as the prevalence of LPV/vaginismus (87).

We could only follow the women until 2009 which limits the time for observation of reproduction. The women in our study were 26-36 years old at the end of the study-period and some may therefore not have started building a family yet. A longer follow-up may have yielded a higher reproductive rate. Despite this, we could observe a lower reproductive rate in women with LPV/vaginismus. Since these women had a higher level of education, more often were unmarried and more often unemployed it was important that we adjusted for these variables since they could possibly independently impact the likelihood of giving birth. Furthermore, we performed a sensitivity analysis where women who were diagnosed after first childbirth were included but this did not alter the results significantly, indicating that exclusion was not a source of bias.

We did not have access to data on infertility treatments or e.g. legal abortion which could have provided more information on the reasons for the lower rate of giving birth in women with LPV/vaginismus. One obvious explanation is that the vulvar pain causes a lower frequency or lack of vaginal intercourse and therefor a lower likelihood of conceiving. However, we do not know if these women suffer from involuntary childlessness or if there are other reasons for the observed lower reproduction. E.g. maybe these women find a suitable partner later in life or do not desire to have any children? Also, according to data from the ANC these women more often reported use of tobacco before and during early pregnancy. These data were only available for women who gave birth. However, one could speculate that this may indicate that women with LPV/vaginismus may in general use tobacco more often. Smoking is associated to a lower fertility (100) which may therefore partly explain the lower reproduction. Further studies are needed to investigate the reasons behind the lower reproductive rate in these women.

We found an increased risk of perineal lacerations (degree 1-4) in women with LPV/vaginismus after adjustment for birthweight $>4000 \mathrm{~g}$, sociodemographic variables and 
mode of delivery. When stratifying on diagnosis (LPV or vaginismus) it was found the observed increase was only significant for women with only vaginismus. In a clinical setting it is primarily severe perineal lacerations involving the anal sphincter (degree 3-4) that are interesting because of the increased morbidity associated with this injury. In women diagnosed with vaginismus there was a small but significant increased risk of anal sphincter injuries $(3.6 \%$ vs $2.2 \%$, $\mathrm{p}=0.009)$. Known risk factors for perineal lacerations are a higher birthweight, instrumental vaginal delivery, primiparity, induction and augmentation of labor, epidural anesthesia and abnormal cephalic presentation (101). We adjusted for mode of delivery and birthweight $>4000 \mathrm{~g}$. The use of pain relief during labor, abnormal cephalic presentation and induction and augmentation of labor did not differ between the groups and all women were primiparous. Therefor we consider vaginismus as a risk factor for perineal laceration involving the anal sphincter. However, the increased risk was small.

We did not adjust for previous psychiatric illness which is a risk factor for CSMR and the prevalence of psychiatric illness is probably higher in women with LPV/vaginismus and may therefore be a source of confounding.

The use of pain-relieving methods during labor were similar in women with and without LPV/vaginismus which was surprising. One would expect women with LPV/vaginismus would benefit from more pain-relief because of concurrent pain. We do not know the reason for this. Maybe the women did indeed not feel a need for more pain-relief or the caregiver did not provide enough information or offered available pain-relivers. As these women had a slight increased risk of emergency CS one wonders whether a better pain-relief would have been able to avert some CSs. Further research is needed to investigate the cause of this.

One must also consider the draw-backs of a register-based design. We know that the women in our study at some time-point during the years 2001-2009 were diagnosed with LPV/vaginismus, but we do not know whether they had any symptoms during pregnancy or childbirth. According to a previous study, the spontaneous recovery rate of vulvodynia without relapse was approximately $50 \%$ during a time period of 30 months in women with vulvodynia. $40 \%$ of the women had a remission but also suffered a relapse during that time period (102). Therefore, some of the women in our study may not actually suffer from LPV/vaginismus at the time of childbirth. This has possible implications on our results as it 
may dilute the differences between the two groups as some of the women may be misclassified at that time point.

In the study for paper IV we used a different study population. This was, to our knowledge, the first long-term follow up of women with primary FOC. By following these women 7-14 years after their first childbirth we were able to observe the reproductive and obstetric outcomes during most of their childbearing years which is a major strength.

Unfortunately, many women chose not to participate in our study which decreased the sample size as well as the generalizability of our findings. E.g. in comparing mode of delivery in second childbirth after previous vaginal childbirth there was a difference in the distribution of mode of delivery where the index women seemed to give birth by planned CS more often. However, there were only four women giving birth by CS which is why these differences should be interpreted with caution.

The drop-out rate was higher in the index group. This differential drop-out may have biased the results. We do not know the reason for non-participation. One could speculate women who were not satisfied with the care given would be less likely to participate. Drop-out analysis showed women who participated had more often given birth by emergency CS or had complications during pregnancy and delivery in their first childbirth. These are factors associated with FOC and could have implications on future reproduction and obstetric outcomes and these differences might have biased our results and lowers the generalizability. It was surprising that women with complications in their first childbirth were more likely to participate. One could speculate that caregivers were better able to take care of women with medical complications and they are perhaps therefore more satisfied. However, a normal vaginal childbirth may be traumatic and in need of increased attention from caregivers, but this may not always be apparent. The other way around, women with complications may feel more motivated to participate in research to learn more and to prevent their complications from happening again. For some women with severe FOC the invitation to participate in the study may have evoked traumatic memories and distress. Indeed, some women promptly stated that they did not want to participate in the study or receive any more information about the study. Hence one could hypothesize that we may not have reached those women with the most severe FOC as it may have been too distressing for them to answer the questionnaire. This has implications on primarily the generalizability of the results as we did not reach all women. However, this was to our knowledge the first study of its kind and provides some increased understanding about the long-term outcomes after treatment for FOC. 
Besides lowering the generalizability due to drop-out and differential drop-out bias the low participation rate decreased the power of our study. This increases the risk of type II-errors, i.e. failure to reject the null-hypothesis when it is false. Therefor the observed lack of difference in e.g. the rate of complications during pregnancy and childbirth should be interpret with caution as it may be due to lack of power to detect such differences.

We had to exclude women not fluent in Swedish which is an important limitation that lowers the generalizability since many women in Sweden are foreign born and these women are more likely to suffer from FOC (13).

In a follow-up several years after childbirth one may question the accuracy in assessing birth experience for example. Larsson et al (37) measured birth experience two months and one year postpartum and found the negative birth experience persisted after one year. Simkin $\mathrm{P}$ found women giving birth for over 20 years ago have vivid and accurate memories of their first childbirth (103).

To our knowledge no one has measured FOC after the childbearing years. The most common instrument for measuring FOC in research is The Wijma Delivery/Expectancy Questionnaire (W-DEQ)(104). However, it is extensive and time-consuming to fill out. Therefor we used a NRS to measure FOC. Similar measurements have been used in previous studies $(19,29)$, but our cut-off was arbitrary. In choosing a high cut-off at NRS 9 we wanted to identify those with severe FOC. This lowers the sensitivity; a lower cut-off would have yielded an even higher prevalence of FOC.

The women in our study gave birth for the first time in 2001-2007 and were contacted in 2015. Therefore, the time for follow-up ranged from 7-14 years. A longer follow-up time may increase the likelihood of giving birth again. However, there was no significant difference in years since first childbirth in the index group compared to the reference group. We therefore chose to include the full range of time to observe as much as possible of the reproductive years. When limiting the time for observation to seven years after first childbirth the results did not alter significantly. 


\section{Principal findings in light of other research}

Before this thesis was initiated several studies had indicated a higher prevalence of psychiatric disorders among women with FOC. Rouhe et al compared psychiatric care 5-12 years before and after childbirth in women referred for treatment of FOC compared to women without FOC. Using national health registers in Finland, they found women with FOC more often suffered from psychiatric disorders both before (31.6\% vs 16.6\%) and after childbirth (44.6\% vs $25.9 \%)$. The most important risk factors for psychiatric care after childbirth was previous mental health problems and FOC. In common with our findings they found all women had an increased risk of psychiatric care after childbirth, but the risk estimates were lower in women with FOC (28). Nordeng et al found women with FOC use psychotropic medications more often before and during pregnancy even without a psychiatric disorder (11). We found a lower prevalence of psychiatric disorders than previous studies have reported. The estimated 12-month prevalence of psychiatric disorders in Europe was 14\% for anxiety disorders, 7.8\% mood disorders and 3.4\% alcohol dependence (105). Rouhe et al, comparing women with and without FOC found the prevalence of psychiatric care to be $31.6 \%$ vs $16.6 \%$ during the 5-12 years before childbirth (28). We found the prevalence of psychiatric outpatient care to be $10 \%$ vs $3.5 \%$ during the five years before childbirth. These differences might be because of the longer study period in Rouhe's study and that not all women with FOC give birth by CSMR. The study population differed from ours including multiparae, older women as well as foreign born women. The prevalence of psychiatric disorders increases with age and may be more common in foreign born women.

Furthermore, there is an under coverage in the NPR and considering that the reporting from the outpatient care started first in 2001 we find a lower prevalence due to lack of data (87).

Our results in paper III are in line with previous studies although research on obstetric outcomes in women with vulvodynia is scarce. A study in Israel during the years 1988-2007 found vaginismus was an independent risk factor for CS and maternal request was one of the primary indications (83). A study in USA found women with vulvodynia tended to more often give birth by CS although the results were not statistically significant $(\mathrm{p}=0.07)$ probably due to lack of power. They also found, among women with vulvodynia, decreased odds of pregnancy in women with pain that limited vaginal intercourse and in constant versus intermittent vulvar pain (84).

We found women with LPV/vaginismus primarily had an increased risk of giving birth by 
CSMR. We do not know the reason for this. It may indicate FOC among these women or a fear of worsened vulvar symptoms after vaginal delivery. However, we have found no study comparing vulvar pain after vaginal versus CS childbirth in women with vulvodynia or vaginismus. According to clinical experience, the common view is that the symptoms decrease after a vaginal delivery why this is an interesting subject for further research. It has previously been hypothesized that women with vaginismus may have an increased risk of pelvic floor injury due to inability to relax and allow for stretching during the second stage of labor (106). This hypothesis was strengthened in our study as women with vaginismus had an increased risk of third to fourth degree perineal laceration. However, further studies are needed to establish the pathophysiology of this increased risk.

Paper IV was the first long term follow up of women with primary FOC. Our results are in line with previous studies which have found women with FOC more often give birth by CS $(25,37,107-110)$ and experience their childbirth as less positive $(24,25,37,38,107-109$, 111). Previous studies have found women treated for FOC more often consider not having any more children (37) and a negative birth experience has been shown to prolong the interval to the next childbirth $(45,112)$. We found women with FOC in their first pregnancy gave birth to a second child to the same extent as the other women, however there were fewer who gave birth more than twice. We do not know if this lower number of childbirths was voluntary, but we found no difference in the rate of infertility treatments among the two groups. The difference may be because women with FOC indeed have a lower reproductive rate due to fear. Possible confounding factors must be considered. Previous studies have found these women more often are unemployed, single and have a low social support why it may be that they do not have the necessary means to support another child or lack a suitable partner. In our study these women were slightly older at childbirth and were more often unemployed at follow-up which are possible confounders that must be taken into consideration when interpreting the results.

We found, as did Larsson et al, that FOC persists after counselling. In Larsson's study $40.7 \%$ vs $13.0 \%$ of women who received counselling still experienced FOC one year after childbirth compared to women without FOC/counselling during pregnancy. We found a lower prevalence of FOC after childbirth (18.0\% vs 5.3\%) however we had a longer follow-up and measured FOC differently compared to Larsson et al. (37). 
Previous studies have found women with FOC differ in personality by being more anxiety prone $(24,25)$ and these differences in personality may partly explain why FOC persist despite exposure to childbirth and counselling.

\section{Clinical implications}

This thesis adds to the general knowledge of women with FOC and women with LPV/vaginismus. These findings illustrate the vulnerability in women with FOC, many suffer from severe psychiatric illness and we found the fear can persist throughout the reproductive years. This is important to consider when counselling these women and in deciding on mode of delivery. Our results implicate one should take these women's wishes seriously and not dismiss them as a wish to plan the date of birth as has sometimes been suggested in the debate. These women are sensitive to psychiatric illness and may be at increased risk of being traumatized by childbirth. However, based on our studies, we do not know if these women's mental health or FOC would have improved given another mode of delivery. Clinicians should be aware of this increased psychiatric morbidity and the ANC should screen for psychiatric disorders. This should be considered when counselling these women and when deciding on mode of delivery. Furthermore, our results indicate one should not expect all women to be cured by counselling and exposure to childbirth as many women still suffered from FOC and required counselling in subsequent pregnancies.

Our study of women with LPV/vaginismus showed these conditions are rarely diagnosed compared to other studies which indicate that these conditions may need increased attention among caregivers. We must ask about these symptoms as it may be perceived as difficult to address by the woman herself. Furthermore, since previous research has shown many women do not seek medical healthcare for these symptoms we may need to provide more information to the public about these conditions. There is an increasing awareness regarding dyspareunia but as the National Board of Health and Welfare in Sweden concluded in their recent report, national guidelines are lacking and we must increase the knowledge in healthcare and provide better information to those patients affected (113).

We found LPV/vaginismus are associated with an increased risk of giving birth by CSMR and therefore may be a source of FOC. Further studies are needed to evaluate the association between LPV/vaginismus and FOC as well as its implications on reproduction and childbirth. It may also be that these women fear worsened symptoms after a vaginal delivery, however we have found no research comparing vulvar pain after vaginal versus CS childbirth in 
women with LPV/vaginismus why further research is needed. Furthermore, women with LPV/vaginismus seemed to be less likely to give birth and women with vaginismus had an increased risk of perineal lacerations. This stress the importance of not only addressing sexual function in these women but reproductive function as well. This was, to our knowledge, one of the first large epidemiological studies in this area. Further studies are needed to confirm our findings and based on this one could optimize the care regarding conception, pregnancy and childbirth in these women.

\section{Further research}

Future research should include foreign born women since this group of women more often suffer from FOC and may have greater difficulties participating in counselling due to e.g. language difficulties. In our study most of the women gave birth vaginally in their first childbirth, but CS was still more common in their second childbirth. Since there were very few women, further studies with larger study populations and preferably a lower drop-out rate are needed to confirm and be able to generalize these findings. We have found CSMR is associated with severe psychiatric illness, however we do not know if a CSMR compared to e.g. planned vaginal childbirth improves their mental health. A larger prospective study where vaginal versus primary CS could be compared would be interesting to see the long-term impact of CSMR in women with FOC.

Further studies on women with LPV/vaginismus are needed to establish how to provide optimal care for these women regarding fertility, antenatal, obstetric and post-partum care. 


\section{Conclusions}

- Women giving birth by CSMR are a vulnerable group more often suffering from severe psychiatric illness both before and after first childbirth.

- Women with LPV/vaginismus are less likely to give birth. When giving birth they have an increased risk of giving birth by CS and women with vaginismus more often suffered from severe perineal lacerations during vaginal childbirth. The higher prevalence of CSMR among these women may indicate FOC among these women.

- FOC is not easily treated and many women require counselling in subsequent pregnancies. Despite counselling and exposure to childbirth about one in five of women experienced severe FOC 7-14 years after first childbirth. 


\section{Populärvetenskaplig sammanfattning}

\section{Hälsa och barnafödande hos kvinnor med primär förlossningsrädsla}

Många kvinnor upplever en viss rädsla inför att föda barn men för vissa kvinnor blir rädslan så stark att den väcker en stor oro som präglar hela graviditeten. Ungefär en av tio gravida kvinnor upplever svår förlossningsrädsla.

Rädslan bottnar ofta i en oro för smärta, att skada barnet eller sig själv, bristande förtroende för vårdpersonalen, bristande tro på sin egen förmåga att föda barn och en rädsla för att förlora kontrollen. Hos kvinnor som tidigare har fött barn är rädslan ofta kopplat till en tidigare negativ förlossningsupplevelse eller ett akut kejsarsnitt till exempel.

Ungefär en tredjedel av alla kvinnor med förlossningsrädsla vill helst föda barn med kejsarsnitt som då görs utan medicinsk anledning, ett så kallat kejsarsnitt på psykosocial indikation. I Sverige erbjuds förlossningsrädda behandling i form av samtal på kvinnokliniken med målet att minska kvinnans rädsla, antalet planerade kejsarsnitt och att nå en positiv förlossningsupplevelse. I slutet av behandlingen kommer kvinnan och vårdgivaren överens om en förlossningsplan som ibland kan innebära ett planerat kejsarsnitt.

En annan grupp med ökad risk för kejsarsnitt på psykosocial indikation är kvinnor med samlagssmärta.

Syfte med dessa studier var att undersöka den psykiska ohälsan före och efter förlossning hos kvinnor som föder barn med kejsarsnitt på psykosocial indikation i deras första förlossning. Vi undersökte också det fortsatta barnafödandet hos kvinnor som fått behandling för förlossningsrädsla i sin första graviditet och om och hur kvinnor med samlagssmärta föder barn.

Genom sammanlänkning av information från flera nationella register i Sverige kunde vi finna att kvinnor som föder barn med kejsarsnitt på psykosocial indikation oftare har fått vård på grund av psykisk sjukdom både före och efter förlossningen. Psykisk sjukdom före förlossningen var kopplat till en ökad risk för att föda barn med kejsarsnitt på psykosocial indikation. Likaså såg vi att kvinnor som hade fött barn med kejsarsnitt på psykosocial indikation hade en ökad risk för psykisk sjukdom fem år efter förlossningen.

I studie III studerade vi hur och om kvinnor som har blivit diagnosticerade med samlagssmärta (definierat som smärta i slidöppningen, "vestibulit" och/eller slidkramp, "vaginism”) föder barn. Även i denna studie användes data från nationella register. Vi fann att kvinnor med samlagssmärta föder barn i mindre utsträckning än andra kvinnor. Om de föder 
barn har de en ökad risk för att förlösas med kejsarsnitt, framförallt kejsarsnitt på psykosocial indikation. För kvinnor med slidkramp sågs en något ökad risk för svår bristning som involverar ändtarmsmuskeln.

I studie IV följde vi upp kvinnor som fătt behandling för förlossningsrädsla i sin första graviditet. De jämfördes mot kvinnor utan förlossningsrädsla i sin första graviditet. Vi fann att kvinnor som hade fått behandling för förlossningsrädsla oftare födde barn med kejsarsnitt $i$ sina första två förlossningar och hade en sämre förlossningsupplevelse i sin första förlossning. Vi fann också att de flesta kvinnorna som fått behandling för förlossningsrädsla i sin första graviditet även behövde behandling i efterföljande graviditeter. Ungefär en av fem av kvinnor som fått behandling var fortfarande förlossningsrädda 7-14 år efter första förlossningen. Detta trots att de hade genomgått behandling och hade egen erfarenhet av att föda barn. Kvinnor med förlossningsrädsla födde sällan fler än två barn jämfört med kvinnorna utan förlossningsrädsla.

Sammanfattningsvis visar denna avhandling att kvinnor med svår förlossningsrädsla som föder barn med kejsarsnitt på psykosocial indikation är en vulnerabel grupp som lider av en hög belastning av psykisk ohälsa. Förlossningsrädsla är svårbehandlat och många kvinnor fortsätter att vara rädda även efter att ha genomgått förlossning och behandling. Vår studie på kvinnor med samlagssmärta indikerar att samlagssmärta kan vara en orsak till förlossningsrädsla och visar också hur viktigt det är att inte bara uppmärksamma sexuell funktion hos dessa kvinnor utan också barnafödande och fertilitet. 


\section{Acknowledgements}

I would like to express my gratitude to my main supervisor Professor Gunilla Sydsjö. Thank you for all your invaluable input, interesting discussions, never-ending enthusiasm and for all the nice time we have spent together!

Thank you, Professor Ann Josefsson and Dr Caroline Lilliecreutz, my co-supervisors, for all your inspiration, invaluable input and support throughout this process!

Marie Bladh, thank you for making statistics understandable! You are amazing at explaining in such a way that I can understand. Especially many thanks for the company in your office, we have shared many great laughs.

Thank you Dr Pia Nordanskog and Senior Professor Göran Berg for your careful review of my progress at my half-time seminar.

I would also like to thank Dr Ninnie Borendahl Wodlin, Dr Emilia Berin, Dr Gabriella Falk and Dr Elizabeth Nedstrand for carefully reviewing my manuscripts and Dr Kristina Kernell and Professor Jan Brynhildsen for providing useful feedback on my "kappa".

I would also like to thank the participants in our research, you provide us with valuable knowledge that hopefully will improve future healthcare.

Last, but not least, I would like to thank my family; my husband Robin and my daughters Vera and Mira for supporting me and bringing me such joy. My parents Monica and Richard for always supporting me, believing the best for me and for raising me to be the person I am today.

Thank you! 


\section{References}

1.Adams SS, Eberhard-Gran M, Eskild A. Fear of childbirth and duration of labour: a study of 2206 women with intended vaginal delivery. BJOG. 2012;119(10):1238-46.

2.Geissbuehler V, Eberhard J. Fear of childbirth during pregnancy: a study of more than 8000 pregnant women. J Psychosom Obstet Gynaecol. 2002;23(4):229-35.

3.Heimstad R, Dahloe R, Laache I, Skogvoll E, Schei B. Fear of childbirth and history of abuse: implications for pregnancy and delivery. Acta Obstet Gynecol Scand. 2006;85(4):43540.

4.Hildingsson I, Haines H, Karlstrom A, Nystedt A. Presence and process of fear of birth during pregnancy-Findings from a longitudinal cohort study. Women Birth. 2017;30(5):e242e7.

5.Hildingsson I, Nilsson C, Karlstrom A, Lundgren I. A longitudinal survey of childbirthrelated fear and associated factors. J Obstet Gynecol Neonatal Nurs. 2011;40(5):532-43. 6.Jokic-Begic N, Zigic L, Nakic Rados S. Anxiety and anxiety sensitivity as predictors of fear of childbirth: different patterns for nulliparous and parous women. J Psychosom Obstet Gynaecol. 2014;35(1):22-8.

7.Laursen M, Hedegaard M, Johansen C, Danish National Birth C. Fear of childbirth: predictors and temporal changes among nulliparous women in the Danish National Birth Cohort. BJOG. 2008;115(3):354-60.

8.Lukasse M, Schei B, Ryding EL, Bidens Study G. Prevalence and associated factors of fear of childbirth in six European countries. Sex Reprod Healthc. 2014;5(3):99-106.

9.Nieminen K, Stephansson O, Ryding EL. Women's fear of childbirth and preference for cesarean section--a cross-sectional study at various stages of pregnancy in Sweden. Acta Obstet Gynecol Scand. 2009;88(7):807-13.

10.Nilsson C, Lundgren I, Karlstrom A, Hildingsson I. Self reported fear of childbirth and its association with women's birth experience and mode of delivery: a longitudinal populationbased study. Women Birth. 2012;25(3):114-21.

11.Nordeng H, Hansen C, Garthus-Niegel S, Eberhard-Gran M. Fear of childbirth, mental health, and medication use during pregnancy. Arch Womens Ment Health. 2012;15(3):203-9. 12.Storksen HT, Garthus-Niegel S, Adams SS, Vangen S, Eberhard-Gran M. Fear of childbirth and elective caesarean section: a population-based study. BMC Pregnancy Childbirth. 2015;15:221. 
13.Ternstrom E, Hildingsson I, Haines H, Rubertsson C. Higher prevalence of childbirth related fear in foreign born pregnant women--findings from a community sample in Sweden. Midwifery. 2015;31(4):445-50.

14.Björklund U EJ, Gustafsson B B, Hammarström M, Lilliecreutz C, Neiminen K, Nordström L, Ryding E L. Förlossningsrädsla. Stockholm: SFOG; 2017. Report No.: 77. 15.Eriksson C, Westman G, Hamberg K. Content of childbirth-related fear in Swedish women and men--analysis of an open-ended question. J Midwifery Womens Health. 2006;51(2):1128.

16.Fenwick J, Toohill J, Creedy DK, Smith J, Gamble J. Sources, responses and moderators of childbirth fear in Australian women: a qualitative investigation. Midwifery. 2015;31(1):239-46.

17.Haines H, Pallant JF, Karlstrom A, Hildingsson I. Cross-cultural comparison of levels of childbirth-related fear in an Australian and Swedish sample. Midwifery. 2011;27(4):560-7. 18.Raisanen S, Lehto SM, Nielsen HS, Gissler M, Kramer MR, Heinonen S. Fear of childbirth in nulliparous and multiparous women: a population-based analysis of all singleton births in Finland in 1997-2010. BJOG. 2014;121(8):965-70.

19.Rouhe H, Salmela-Aro K, Halmesmaki E, Saisto T. Fear of childbirth according to parity, gestational age, and obstetric history. BJOG. 2009;116(1):67-73.

20.Storksen HT, Garthus-Niegel S, Vangen S, Eberhard-Gran M. The impact of previous birth experiences on maternal fear of childbirth. Acta Obstet Gynecol Scand. 2013;92(3):31824.

21.Lukasse M, Schroll AM, Karro H, Schei B, Steingrimsdottir T, Van Parys AS, et al. Prevalence of experienced abuse in healthcare and associated obstetric characteristics in six European countries. Acta Obstet Gynecol Scand. 2015;94(5):508-17.

22.Lilliecreutz C, Sydsjo G, Josefsson A. Obstetric and perinatal outcomes among women with blood- and injection phobia during pregnancy. J Affect Disord. 2011;129(1-3):289-95. 23.Saisto T, Salmela-Aro K, Nurmi JE, Halmesmaki E. Psychosocial characteristics of women and their partners fearing vaginal childbirth. BJOG. 2001;108(5):492-8.

24.Ryding EL, Wirfelt E, Wangborg IB, Sjogren B, Edman G. Personality and fear of childbirth. Acta Obstet Gynecol Scand. 2007;86(7):814-20.

25.Handelzalts JE, Becker G, Ahren MP, Lurie S, Raz N, Tamir Z, et al. Personality, fear of childbirth and birth outcomes in nulliparous women. Arch Gynecol Obstet.

2015;291(5):1055-62. 
26.Molgora S, Fenaroli V, Prino LE, Rolle L, Sechi C, Trovato A, et al. Fear of childbirth in primiparous Italian pregnant women: The role of anxiety, depression, and couple adjustment. Women Birth. 2017 Jul 11. pii: S1871-5192(16)30158-5. doi: 10.1016/j.wombi.2017.06.022. 27.Rondung E, Thomten J, Sundin O. Psychological perspectives on fear of childbirth. J Anxiety Disord. 2016;44:80-91.

28.Rouhe H, Salmela-Aro K, Gissler M, Halmesmaki E, Saisto T. Mental health problems common in women with fear of childbirth. BJOG. 2011;118(9):1104-11.

29.Storksen HT, Eberhard-Gran M, Garthus-Niegel S, Eskild A. Fear of childbirth; the relation to anxiety and depression. Acta Obstet Gynecol Scand. 2012;91(2):237-42.

30.Ryding EL, Lukasse M, Kristjansdottir H, Steingrimsdottir T, Schei B, and the Bidens study group. Pregnant women's preference for cesarean section and subsequent mode of birth - a six-country cohort study. J Psychosom Obstet Gynaecol. 2016;37(3):75-83.

31.Betran AP, Ye J, Moller AB, Zhang J, Gulmezoglu AM, Torloni MR. The Increasing Trend in Caesarean Section Rates: Global, Regional and National Estimates: 1990-2014. PLoS One. 2016;11(2):e0148343.

32.Stjernholm YV, Petersson K, Eneroth E. Changed indications for cesarean sections. Acta Obstet Gynecol Scand. 2010;89(1):49-53.

33.Karlstrom A, Rådestad IE, C. Rubertsson, C. Nystedt, A. Hildingsson, I. Cesarean Section without Medical Reason, 1997 to 2006: A Swedish Register Study. Birth.37(1):11-20. Doi 10.1111/j.1523-536X.2009.00373.X

34.Wiklund I, Edman G, Andolf E. Cesarean section on maternal request: reasons for the request, self-estimated health, expectations, experience of birth and signs of depression among first-time mothers. Acta Obstet Gynecol Scand. 2007;86(4):451-6.

35.The National Board of Health and Welfare, The Swedish Society of Medicine, Swedish Association of Local Authorities and Regions and Swedish Agency for Health Technology Assessment and Assessment of Social Services. Nationella Medicinska Indikationer. Indikation för kejsarsnitt på moderns önskan. Rapport no 2011:09. Accessed 24th of May 2018. Available at: https://www.socialstyrelsen.se/SiteCollectionDocuments/nationellaindikationer-kejsarsnitt-moderns-onskan.pdf.

36.Larsson B, Karlstrom A, Rubertsson C, Hildingsson I. Counseling for childbirth fear - a national survey. Sex Reprod Healthc. 2016;8:82-7.

37.Larsson B, Karlstrom A, Rubertsson C, Hildingsson I. The effects of counseling on fear of childbirth. Acta Obstet Gynecol Scand. 2015;94(6):629-36. 
38.Ryding EL, Persson A, Onell C, Kvist L. An evaluation of midwives' counseling of pregnant women in fear of childbirth. Acta Obstet Gynecol Scand. 2003;82(1):10-7.

39.Rouhe H, Salmela-Aro K, Toivanen R, Tokola M, Halmesmaki E, Ryding EL, et al. Group psychoeducation with relaxation for severe fear of childbirth improves maternal adjustment and childbirth experience--a randomised controlled trial. J Psychosom Obstet Gynaecol. 2015;36(1):1-9.

40.Rouhe H, Salmela-Aro K, Toivanen R, Tokola M, Halmesmaki E, Saisto T. Obstetric outcome after intervention for severe fear of childbirth in nulliparous women - randomised trial. BJOG. 2013;120(1):75-84.

41.Nerum H, Halvorsen L, Sorlie T, Oian P. Maternal request for cesarean section due to fear of birth: can it be changed through crisis-oriented counseling? Birth. 2006;33(3):221-8. 42.Nieminen K, Andersson G, Wijma B, Ryding EL, Wijma K. Treatment of nulliparous women with severe fear of childbirth via the Internet: a feasibility study. J Psychosom Obstet Gynaecol. 2016;37(2):37-43.

43.Larsson B, Karlstrom A, Rubertsson C, Ternstrom E, Ekdahl J, Segebladh B, et al. Birth preference in women undergoing treatment for childbirth fear: A randomised controlled trial. Women Birth. 2017;30(6):460-7.

44.Sydsjo G, Sydsjo A, Gunnervik C, Bladh M, Josefsson A. Obstetric outcome for women who received individualized treatment for fear of childbirth during pregnancy. Acta Obstet Gynecol Scand. 2012;91(1):44-9.

45.Sydsjo G, Angerbjorn L, Palmquist S, Bladh M, Sydsjo A, Josefsson A. Secondary fear of childbirth prolongs the time to subsequent delivery. Acta Obstet Gynecol Scand. 2013;92(2):210-4.

46. Mollison J, Porter M, Campbell D, Bhattacharya S. Primary mode of delivery and subsequent pregnancy. BJOG. 2005;112(8):1061-5.

47.Lukasse M, Vangen S, Oian P, Kumle M, Ryding EL, Schei B, et al. Childhood abuse and fear of childbirth--a population-based study. Birth. 2010;37(4):267-74.

48.Bornstein J, Goldstein AT, Stockdale CK, Bergeron S, Pukall C, Zolnoun D, et al. 2015 ISSVD, ISSWSH and IPPS Consensus Terminology and Classification of Persistent Vulvar Pain and Vulvodynia. Obstet Gynecol. 2016;127(4):745-51.

49.Vieira-Baptista P, Lima-Silva J, Cavaco-Gomes J, Beires J. Prevalence of vulvodynia and risk factors for the condition in Portugal. Int J Gynaecol Obstet. 2014;127(3):283-7. 
50.Reed BD, Harlow SD, Legocki LJ, Helmuth ME, Haefner HK, Gillespie BW, et al. Oral contraceptive use and risk of vulvodynia: a population-based longitudinal study. BJOG. 2013;120(13):1678-84.

51.Reed BD, Harlow SD, Sen A, Edwards RM, Chen D, Haefner HK. Relationship between vulvodynia and chronic comorbid pain conditions. Obstet Gynecol. 2012;120(1):145-51. 52.Reed BD, Harlow SD, Sen A, Legocki LJ, Edwards RM, Arato N, et al. Prevalence and demographic characteristics of vulvodynia in a population-based sample. Am J Obstet Gynecol. 2012;206(2):170 e1-9.

53.Peixoto MM, Nobre P. Prevalence and sociodemographic predictors of sexual problems in Portugal: a population-based study with women aged 18 to 79 years. J Sex Marital Ther. 2015;41(2):169-80.

54.Harlow BL, Kunitz CG, Nguyen RH, Rydell SA, Turner RM, MacLehose RF. Prevalence of symptoms consistent with a diagnosis of vulvodynia: population-based estimates from 2 geographic regions. Am J Obstet Gynecol. 2014;210(1):40 e1-8.

55.Danielsson I, Sjoberg I, Stenlund H, Wikman M. Prevalence and incidence of prolonged and severe dyspareunia in women: results from a population study. Scand J Public Health. 2003;31(2):113-8.

56.Dargie E, Pukall CF. Women in "Sexual" Pain: Exploring the Manifestations of Vulvodynia. J Sex Marital Ther. 2016;42(4):309-23.

57.Harlow BL, Stewart EG. A population-based assessment of chronic unexplained vulvar pain: have we underestimated the prevalence of vulvodynia? J Am Med Womens Assoc (1972). 2003;58(2):82-8.

58.Voscopoulos C LM. When does acute pain become chronic? Br J Anaesth. 2010;105(Suppl 1):69-85.

59.Tommola P, Unkila-Kallio L, Paetau A, Meri S, Kalso E, Paavonen J. Immune activation enhances epithelial nerve growth in provoked vestibulodynia. Am J Obstet Gynecol. 2016;215(6):768 e1- e8.

60.Reed BD, Sen A, Harlow SD, Haefner HK, Gracely RH. Multimodal Vulvar and Peripheral Sensitivity Among Women With Vulvodynia: A Case-Control Study. J Low Genit Tract Dis. 2017;21(1):78-84.

61.Nguyen RH, Ecklund AM, Maclehose RF, Veasley C, Harlow BL. Co-morbid pain conditions and feelings of invalidation and isolation among women with vulvodynia. Psychol Health Med. 2012;17(5):589-98. 
62.Farmer MA, Taylor AM, Bailey AL, Tuttle AH, MacIntyre LC, Milagrosa ZE, et al. Repeated vulvovaginal fungal infections cause persistent pain in a mouse model of vulvodynia. Sci Transl Med. 2011;3(101):101ra91.

63.Falsetta ML, Foster DC, Woeller CF, Pollock SJ, Bonham AD, Haidaris CG, et al. Identification of novel mechanisms involved in generating localized vulvodynia pain. Am J Obstet Gynecol. 2015;213(1):38 e1-12.

64.Foster DC, Falsetta ML, Woeller CF, Pollock SJ, Song K, Bonham A, et al. Site-specific mesenchymal control of inflammatory pain to yeast challenge in vulvodynia-afflicted and pain-free women. Pain. 2015;156(3):386-96.

65. Gerber S, Bongiovanni AM, Ledger WJ, Witkin SS. Interleukin-1 $\beta$ gene polymorphism in women with vulvar vestibulitis syndrome. Eur J Obstet Gynecol Reprod Biol. 2003 Mar 26;107(1):74-7.

66.Foster DC ST, Stodgell CJ. Impact of genetic variation in interleukin-1 receptor antagonist and melanocortin-1 receptor genes on vulvar vestibulitis syndrome. J Reprod Med 49(7):503-9.

67. Babula O, Danielsson I, Sjoberg I, Ledger WJ, Witkin SS. Altered distribution of mannose-binding lectin alleles at exon I codon 54 in women with vulvar vestibulitis syndrome. Am J Obstet Gynecol. 2004;Volume 191(3):762-6.

68. Heddini U, Bohm-Starke N, Grönbladh A, Nyberg F, Nilsson KW, Johannesson U. Serotonin receptor gene (5HT-2A) polymorphism is associated with provoked vestibulodynia and comorbid symptoms of pain. Journal of Sexual Medicine 2014;11(12):3064-71.

69.Tommola P, Butzow R, Unkila-Kallio L, Paavonen J, Meri S. Activation of vestibuleassociated lymphoid tissue in localized provoked vulvodynia. Am J Obstet Gynecol. 2015;212(4):476 e1-8.

70.Halperin R ZS, Vaknin Z, Ben-Ami I, Pansky M, Schneider D. The major histopathologic characteristics in the vulvar vestibulitis syndrome. Gynecol Obstet Invest. 2005;59(2):75-9. 71.Papoutsis D, Haefner HK, Crum CP, Opipari AW, Jr., Reed BD. Vestibular Mast Cell Density in Vulvodynia: A Case-Controlled Study. J Low Genit Tract Dis. 2016;20(3):275-9. 72.Khandker M, Brady SS, Vitonis AF, Maclehose RF, Stewart EG, Harlow BL. The influence of depression and anxiety on risk of adult onset vulvodynia. J Womens Health (Larchmt). 2011;20(10):1445-51.

73.Iglesias-Rios L, Harlow SD, Reed BD. Depression and posttraumatic stress disorder among women with vulvodynia: evidence from the population-based woman to woman health study. J Womens Health (Larchmt). 2015;24(7):557-62. 
74.Khandker M, Brady SS, Stewart EG, Harlow BL. Is chronic stress during childhood associated with adult-onset vulvodynia? J Womens Health (Larchmt). 2014;23(8):649-56. 75.Bouchard C BJ, Fortier M, Morin C, Blanchette C. Use of oral contraceptive pills and vulvar vestibulitis: a case-control study. Am J Epidemiol. 2002;1(156):254-61.

76.Gupta A, Rapkin AJ, Gill Z, Kilpatrick L, Fling C, Stains J, et al. Disease-related differences in resting-state networks: a comparison between localized provoked vulvodynia, irritable bowel syndrome, and healthy control subjects. Pain. 2015;156(5):809-19.

77.Schweinhardt P KA, Pukall CF, Bushnell MC. Increased gray matter density in young women with chronic vulvar pain. Pain. 2008;140(3):411-9.

78.Hampson JP, Reed BD, Clauw DJ, Bhavsar R, Gracely RH, Haefner HK, et al. Augmented central pain processing in vulvodynia. J Pain. 2013;14(6):579-89.

79. American Psychiatric Association. (2000). Diagnostic and statistical manual of mental disorders: DSM-IV-TR. Washington, DC:

80.Engman M, Lindehammar H, Wijma B. Surface electromyography diagnostics in women with partial vaginismus with or without vulvar vestibulitis and in asymptomatic women. $\mathbf{J}$ Psychosom Obstet Gynaecol. 2004;25(3-4):281-94.

81.Binik YM. The DSM diagnostic criteria for vaginismus. Archives of Sexual Behavior Volume. 2010;39(2):278-91.

82. American Psychiatric Association. (2013). Diagnostic and statistical manual of mental disorders (5th ed.). Washington, DC:

83.Goldsmith T, Levy A, Sheiner E. Vaginismus as an independent risk factor for cesarean delivery. J Matern Fetal Neonatal Med. 2009;22(10):863-6.

84.Nguyen RH, Stewart EG, Harlow BL. A population-based study of pregnancy and delivery characteristics among women with vulvodynia. Pain Ther. 2012;1(1):2.

85.Johnson NS, Harwood EM, Nguyen RH. "You have to go through it and have your children": reproductive experiences among women with vulvodynia. BMC Pregnancy Childbirth. 2015;15:114.

86. National Board of Health and Welfare, Centre for Epidemiology. The Swedish medical birth register; a summary of content and quality. 2003

[www.socialstyrelsen.se/Lists/Artikelkatalog/Attachments/10655/2003-1123_20031123.pdf]. 87. National Board of Health and Welfare, Centre for Epidemiology.Kvalitet och innehåll i patientregistret. 2009 [www.socialstyrelsen.se/publikationer2009/2009-125-15]. Accessed 1 Mars 2018. 
88. National Board of Health and Welfare, Centre for Epidemiology. The Swedish version of 10th revision of WHO's international classification of diseases. 2017 [http://www.socialstyrelsen.se/publikationer2017/2017-4-2]. Accessed 1 Mars 2018. 89.Ludvigsson JF, Andersson E, Ekbom A, Feychting M, Kim JL, Reuterwall C, et al. External review and validation of the Swedish national inpatient register. BMC Public Health. 2011;11:450.

90 Statistics Sweden. A New Total Population Register System. More Possibilities and Better Quality. (Serial no. 2002:2). Örebro, Sweden:Statistics Sweden, 2002.

91.Ludvigsson JF, Almqvist C, Bonamy AK, Ljung R, Michaelsson K, Neovius M, et al. Registers of the Swedish total population and their use in medical research. Eur J Epidemiol. 2016;31(2):125-36.

92. National Board of Health and Welfare, Centre for Epidemiology.Causes of death 2011. 2012 [www.socialstyrelsen.se/Lists/Artikelkatalog/Attachments/19001/2013-2-30.pdf]. Accessed 1 Mars 2018.

93.Brooke HL, Talback M, Hornblad J, Johansson LA, Ludvigsson JF, Druid H, et al. The Swedish cause of death register. Eur J Epidemiol. 2017;32(9):765-73.

94.Statistics Sweden. Educational attainment of the population 2004. 2005[www.scb.se/statistik/UF/UF0506/2005A01/UF0506_2005A01_SM_UF37SM0501.pdf]. Accessed1 Mars 2018.

95. Statistics Sweden. Multi-generation register 2010. A description of contents and quality. 2011

[www.scb.se/statistik/_publikationer/BE9999_2011A01_BR_BE96BR1102.pdf].Accessed 1 Mars 2018.

96.Sydsjo G, Bladh M, Lilliecreutz C, Persson AM, Vyoni H, Josefsson A. Obstetric outcomes for nulliparous women who received routine individualized treatment for severe fear of childbirth - a retrospective case control study. BMC Pregnancy Childbirth. 2014;14:126.

97 National Board of Health and Welfare, Centre for Epidemiology.Translator ICD9 to ICD 10. [http://www.socialstyrelsen.se/klassificeringochkoder/laddaner/Documents/9TO10.PDF]. Accessed 1 Mars 2018.

98. National Board of Health and Welfare. Utvecklingen av psykisk ohälsa bland barn och unga vuxna. Till och med 2016. 2017. [http://www.socialstyrelsen.se/Lists/Artikelkatalog/Attachments/20785/2017-12-29.pdf]. Accessed 29 Aug 2018. 
99. Munk-Olsen T, Laursen TM, Pedersen CB, Mors O, Mortensen PB. New parents and mental disorders: a population-based register study. JAMA. 2006 Dec 6;296(21):2582-9. 100. The Practice Committee of the American Society for Reproductive Medicine, American Society for Reproductive Medicine, Birmingham, Alabama. Smoking and Infertility. Fertility and Sterility. 2008;90(5):S254-S259.

101.Pergialiotis V VD, Protopapas A, Pappa K, Vlachos G. Risk factors for severe perineal lacerations during childbirth. Int J Gynaecol Obstet. 2014;125(1):6-14.

102. Reed BD, Harlow SD, Plegue MA, Sen A J. Remission, Relapse, and Persistence of Vulvodynia: A Longitudinal Population-Based Study.Womens Health (Larchmt). 2016 Mar;25(3):276-83. doi: 10.1089/jwh.2015.5397.

103. Simkin P. Just another day in a woman's life? Women's long-term perceptions of their first birth experience. Part I. Birth. 1991 Dec;18(4):203-10.

104.Wijma K, Wijma B, Zar M. Psychometric aspects of the W-DEQ; a new questionnaire for the measurement of fear of childbirth. J Psychosom Obstet Gynaecol. 1998;19(2):84-97. 105.Wittchen HU, Jacobi F, Rehm J, Gustavsson A, Svensson M, Jonsson B, et al. The size and burden of mental disorders and other disorders of the brain in Europe 2010. Eur Neuropsychopharmacol. 2011;21(9):655-79.

106.Rosenbaum TY, Padoa A. Managing pregnancy and delivery in women with sexual pain disorders. J Sex Med. 2012;9(7):1726-35; quiz 36.

107.Haines HM, Rubertsson C, Pallant JF, Hildingsson I. The influence of women's fear, attitudes and beliefs of childbirth on mode and experience of birth. BMC Pregnancy Childbirth. 2012;12:55.

108.Laursen M, Johansen C, Hedegaard M. Fear of childbirth and risk for birth complications in nulliparous women in the Danish National Birth Cohort. BJOG. 2009;116(10):1350-5.

109.Ryding EL, Lukasse M, Parys AS, Wangel AM, Karro H, Kristjansdottir H, et al. Fear of childbirth and risk of cesarean delivery: a cohort study in six European countries. Birth. 2015;42(1):48-55.

110.Waldenstrom U, Hildingsson I, Ryding EL. Antenatal fear of childbirth and its association with subsequent caesarean section and experience of childbirth. BJOG. 2006;113(6):638-46.

111.Elvander C, Cnattingius S, Kjerulff KH. Birth experience in women with low, intermediate or high levels of fear: findings from the first baby study. Birth. 2013;40(4):28996. 
112.Gottvall KW, Ulla.Does a traumatic birth experience have an impact on future reproduction? BJOG: An International Journal of Obstetrics \& Gynaecology. 2002;109(3):254-60.

113. National Board of Health and Welfare. Kartläggning av vestibulit. 2018. Accessed 06 Feb 2019. Available at

https://www.socialstyrelsen.se/Lists/Artikelkatalog/Attachments/20986/2018-6-16.pdf. 


\section{Papers}

The papers associated with this thesis have been removed for copyright reasons. For more details about these see:

http://urn.kb.se/resolve?urn=urn:nbn:se:liu:diva-156622 


\section{FACULTY OF MEDICINE AND HEALTH SCIENCES}

Linköping University Medical Dissertation No. 1681, 2019

Department of Obstetrics and Gynaecology

Department of Clinical and Experimental Medicine

Linköping University

SE-581 83 Linköping, Sweden

www.liu.se 